\title{
A Biphasic Change in Ribosomal Conformation during Transneuronal Degeneration Is Altered by Inhibition of Mitochondrial, but Not Cytoplasmic Protein Synthesis
}

\author{
Gwenn A. Garden, ${ }^{1,2}$ Karen S. Canady, ${ }^{2}$ Diana I. Lurie, ${ }^{2}$ Mark Bothwell, ${ }^{1}$ and Edwin W Rubel ${ }^{1,2}$ \\ Virginia Merrill Bloedel Hearing Research Center, Departments of ${ }^{1}$ Physiology and Biophysics and ${ }^{2} \mathrm{Otolaryngology-Head}$ \\ and Neck Surgery, University of Washington School of Medicine, Seattle, Washington 98195
}

Following loss of eighth nerve input, $20-40 \%$ of neurons in the neonatal chick cochlear nucleus, nucleus magnocellularis (NM), undergo cell death. Intracellular changes that precede the death of NM neurons include increased oxidative metabolism and mitochondrial volume, decreased cytoplasmic protein synthesis, and destruction of ribosomes. Six hours following afferent deprivation, dying NM neurons demonstrate complete loss of ribosomes and cessation of protein synthesis, suggesting that the rapid destruction of ribosomes leads to neuronal death. Increased NM neuron death occurs when mitochondrial upregulation is prevented by chloramphenicol, a mitochondrial protein synthesis inhibitor. This finding suggests that increased oxidative capacity is required for neuronal survival following loss of afferent input.

To study changes in the ribosomes of afferent-deprived NM neurons, we obtained a monoclonal antibody to ribosomal RNA. This monoclonal antibody, $Y 10 B$, labels ribosomes of all NM neurons receiving normal synaptic activity. Following removal of afferent input, NM neurons demonstrate a biphasic change in their pattern of $Y 10 B$ label. During the initial phase, there is a uniform decrease in the density of Y10B label. In the second phase, some NM neurons recover the capacity to bind the $\mathrm{Y} 10 \mathrm{~B}$ antibody while others remain unlabeled. During this second phase, NM neurons putatively destined to die, based on their failure to synthesize protein, are unlabeled by the $\mathrm{Y} 10 \mathrm{~B}$ antibody.

New gene expression is not necessary to initiate the change in ribosomal immunoreactivity that leads deafferented NM neurons toward cell death. Blocking cytoplasmic protein synthesis with cycloheximide had no effect on the biphasic change in $Y 10 B$ labeling of afferent-deprived NM neurons. Treating chicks with chloramphenicol, however, prevented the recovery of $\mathrm{Y} \mathrm{OB}_{\mathrm{O}} \mathrm{immunoreactivity} \mathrm{in} \mathrm{NM} \mathrm{neurons} \mathrm{during}$ the second phase of the response to afferent deprivation.

[Key words: neuronal death, afferent deprivation, nucleus magnocellularis, ribosome, mitochondria, protein synthesis]

\footnotetext{
Received Mar. 23, 1993; revised Sept. $\overline{8}, 1993$; accepted Sept. 21,1993

This work was supported by NIH Grants DCO0520 (E.WR.) and NS23343 (M.B.), NIH Training Grants GM07266 (G.A.G) and DC00018 (K.S.C.), and a University of Washington Royalty Research Fund Award (M.B.). We also thank Dr. Joan Steitz for the generous gift of the Y $10 \mathrm{~B}$ hybridoma, Jialin Shang for technical assistance, Paul Schwarty and Janet Clardy for photographic assistance, Dr. Richard L. Hyson and Dr. William R. Lippe for advice in statistical analysis, and Maike Hartlage-Rubsamen and Dr. Jennifer Stone for comments on a previous version of the manuscript.

Correspondence should be addressed to Edwin W. Rubel, Department of Otolaryngology, Hearing Development Laboratories, RL-30, University of Washington, Seattle, WA 98195

Copyright $\subseteq 1994$ Society for Neuroscience $0270-6474 / 94 / 141994-15 \$ 05.00 / 0$
}

Neurons in the neonatal chick cochlear nucleus, nucleus magnocellularis (NM), exhibit nearly simultaneous activation of survival and suicide mechanisms in response to loss of afferent input from the eighth nerve. Following deafferentation or blockade of afferent excitatory activity, NM neurons in young animals undergo a series of rapid intracellular changes that eventually result in the death of $20-40 \%$ of the population (Rubel et al., 1990). Decreased protein synthesis, measured by incorporation of ${ }^{3} \mathrm{H}$-leucine, is an early response of $\mathrm{NM}$ neurons to afferent deprivation (Stcward and Rubel, 1985; Born and Rubel, 1988). Following loss of afferent input, all NM neurons demonstrate decreased ${ }^{3} \mathrm{H}$-leucine incorporation, but by $6 \mathrm{hr}$, two distinct populations of NM neurons can be identified. One population continues to incorporate ${ }^{3} \mathrm{H}$-leucine at a rate slightly reduced from normal, while the remainder appear to cease entirely incorporation of the amino acid label.

Several lines of evidence suggest that those NM neurons that have ceased protein synthesis 6 hr after cochlea removal are the cells that will eventually die (Rubel et al., 1991). For example, electron microscopic evidence shows complete ribosomal destruction in those cells that are no longer synthesizing protein $6 \mathrm{hr}$ following deafferentation (Rubel et al., 1991). Despite these degradative changes, if synaptic activity is restored after $6 \mathrm{hr}$ of afferent activity blockade, no neuronal death ensues (Born and Rubel, 1988).

The rapid metabolic and ultrastructural changes observed in NM neurons following the cessation of eighth nerve input support the hypothesis that an active cellular mechanism leading to neuronal death is negatively regulated by the trophic influence of afferent activity. Decreased protein synthesis (MacDonald and Cidlowski, 1982) and degradation of RNA (Cidlowski, 1982; $\mathrm{Al}$ Goul and Miller, 1989) have also been observed early in the process of developmental or programmed cell death in other systems. These early changes may play important roles in the series of events that eventually culminates in the death of a neuron.

Recent findings support the theory that developmental neuronal death results from an active process (Oppenheim et al., 1990; Ellis et al., 1991; Franklin and Johnson, 1992; Martin et al., 1992). Like many examples of programmed cell death in non-neuronal cells, neuronal death during chick embryogenesis (Oppenheim et al., 1990), or in response to trophic factor deprivation in vitro (Martin et al., 1988; Scott and Davies, 1990), appears to require new protein synthesis. These findings suggest that specific genes must be expressed in order for the cell to differentiate into a dying neuron.

Afferent-deprived NM neurons also exhibit increased activity 
of enzymes involved in oxidative metabolism (Durham and Rubel, 1985; Hyde and Durham, 1990; Durham et al., 1993). These changes are coupled with an increase in mitochondrial density, evident $6 \mathrm{hr}$ after cochlea removal (Hyde and Durham, 1993b). Inhibiting mitochondrial upregulation with the drug chloramphenicol produces an increase in the number of NM neurons that will die in response to deafferentation (Hyde and Durham, 1993a) and an increase in the number of neurons demonstrating degradation of ribosomes $6 \mathrm{hr}$ after afferent deprivation (Hartlage-Rubsamen et al., 1992). These results are consistent with the hypothesis that the increase in mitochondrial density and oxidative function observed in afferent-deprived NM neurons is an indicator of a survival mechanism involved in arresting or reversing the cell death process. Mechanisms that prevent lymphocyte apoptosis (Hockenbery et al., 1990) or programmed cell death during invertebrate neuronal development (Ellis et al., 1991) have also been described. Overexpression of the $b c l-2$ gene product prevents neuronal death triggered during normal development (Vaux et al., 1992) or trophic factor deprivation (Garcia et al., 1992). Little is known about the molecular or enzymatic function of the $b c t-2$ gene product. The localization of this protein to mitochondria, however, suggests that the cell survival program that it promotes may involve that organelle system.

Bidirectional regulation of the cell death phenotype is suggested by the existence of a survival mechanism. In such a scheme, the ultimate fate of a cell is detcrmined by the balance between the influences of the suicide program and of the opposing survival mechanisms. To elucidate further the biochemical mechanisms involved in the theorized survival and suicide programs, inhibitors of cytoplasmic and mitochondrial protein synthesis could be employed. However, marking the neuronal death process in NM entailed cumbersome ${ }^{3} \mathrm{H}$-leucine autoradiography to demonstrate decreased ribosomal function or electron microscopic evidence of ribosome degradation or dissociation. Wc hypothesized that an antibody to ribosomal RNA (rRNA) may be a more useful marker of the extent of rRNA degradation in these cells. A monoclonal antibody to rRNA, Y 10B, had been generated from a genetic mouse model of autoimmune disease (Lerner et al., 1981). The Y10B antibody immunoprecipitates whole ribosomes as well as all sizes of phenol-extracted rRNA, indicating that it recognizes a nucleic acid Inotif comnon to many rRNAs (Lemer et al., 1981; G. Garden, E. Rubel, and M. Bothwell, unpublished observations). Using the Y10B antibody as a marker of those cells undergoing ribosome degradation, we addressed three questions regarding the process of afferent-deprivation-induced cell death in NM neurons. First, we examined whether altered Y10B immunoreactivity could be used to identify neurons undergoing the metabolic sequence of events leading to cell death. Second, we examined whether the changes in rRNA immunoreactivity resulted from the induction of genes not constitutively expressed in these neurons. Third, we examined whether blocking mitochondrial protein synthesis with chloramphenicol treatment would alter the pattern of change in Y10B immunoreactivity normally observed in afferent-deprived NM neurons.

\section{Materials and Methods}

\section{Animals}

All experimental and control animals were 10-14-d-old White Leghorn chickens. Eggs, obtained from a local supplier (H\&N, Redmond, WA), were incubated and hatched at the University of Washington vivarium in AAALAC-approved facilities. Food and water were freely available to the animals at all times. To characterize the level of Y $10 \mathrm{~B} \mathrm{immu-}$ noreactivity in NM neurons following afferent activity deprivation, three to five animals were sacrificed $3,6,9$, or $12 \mathrm{hr}$ following cochlea removal and one to three animals were sacrificed 3 or $6 \mathrm{hr}$ following afferent activity blockade by tetrodotoxin (TTX) placement in the cochlea (Canady and Rubel, 1992). Three animals were sacrificed as unoperated controls. The cycloheximide and chloramphenicol treatment studies each contained three to five expcrimental animals and three to five controls for each time point at which animals were sacrificed. All procedures involving experimental animals were reviewed and approved by the University of Washington Animal Care Committee.

Cochlea removal. Afferent deprivation of NM neurons on the right side of the brainstem was produced in most experimental animals by unilateral removal of the right basilar papilla (cochlea). The left cochica remained intact so that the left NM could serve as a within-animal control. The right cochlea was removed according to the method of Born and Rubel (1985). Briefly, chicks were deeply anesthetized with ketamine ( $80 \mathrm{mg} / \mathrm{kg}$ body weight) and sodium pentobarbital $(15 \mathrm{mg} / \mathrm{kg}$ body weight). Two $5 \mathrm{~mm}$ incisions were made to widen the external ear canal. With a pair of \#5 Dumont forceps the tympanic membrane was punctured, the middle ear ossicle removed and the cochlea pulled out through the oval window. The cochlea was examined under a dissecting microscope to ensure the complete removal of the receptor organ. The middle ear cavity was then filled with Gelfoam, and the external incisions were cleaned and closed with cyanoacrylate adhesive. This procedurc leaves the cell bodies and proximal axons of eighth nerve ganglion cells intact. The ganglion cells begin to degenerate $12-18 \mathrm{hr}$ later (Born and Rubel, 1985).

Eighth nerve activity blockade. Electrical activity in the eighth nerve was silenced unilaterally by intralabyrinthine placement of TTX according to the method of Canady and Rubel (1992). Briefly, chicks were deeply anesthetized with ketamine $(80 \mathrm{mg} / \mathrm{kg}$ body weight) and sodium pentobarbital $(15 \mathrm{mg} / \mathrm{kg}$ body weight). An incision was made to expose the thin bone overlying the vestibule and $0.1 \mathrm{mg}$ of a TTX suspension in the slow-release compound Elvax (Du Pont) was placed into the perilymph through this bone. The skin was then closed over the wound. Effectiveness of the TTX activity blockade was assessed in each experimental animal by monitoring auditory evoked potentials prior to and following TTX injections (Born and Rubel, 1988; Canady and Rubel, 1992).

Protein synthesis inhibition. To determine the proper dose of the protein synthesis inhibitor cycloheximide for this age chick, test animals $(n=2)$ were lightly anesthetized by halothane inhalation. Varying doses of cycloheximide were administered by intracerebral injection. Control animals were similarly anesthetized and injected with an equal volume of sterile saline. A $250 \mu \mathrm{g}$ dose of cycloheximide produced a $95 \%$ inhibition of incorporation of ${ }^{3} \mathrm{H}$-leucine into brainstem protein precipitated with trichloroacetic acid for at least $3 \mathrm{hr}$. Once this dose was determined, two groups of animals were examined for an effect of protein synthesis inhibition on deafferentation-induced changes in Y10B immunoreactivity. The first group was injected with cycloheximide immediately following removal of the cochlea and these animals were sacrificed $3 \mathrm{hr}$ later. The second group was injected with cycloheximide $6 \mathrm{hr}$ following cochlca removal under light halothanc ancsthesia and sacrificed $3 \mathrm{hr}$ later. Untreated, control animals received intracerebral injections of sterile saline on the same schedule. At the appropriate death time, control and cycloheximide-treated chicks were deeply anesthetized and transcardially perfused with $0.9 \%$ saline for $1-2 \mathrm{~min}$ followed by $4 \%$ paraformaldehyde for $10 \mathrm{~min}$.

Mitochondrial protein synthesis inhibition. Three experimental groups of chicks were treated with chloramphenicol, an inhibitor of mitochondrial protein synthesis and proliferation. The experimental groups were sacrificed 3,6 , and $12 \mathrm{hr}$ after unilateral cochlea removal. For the 6 and $12 \mathrm{hr}$ survival groups, chloramphenicol was administered according to the protocol of Hyde and Durham (1993a). Osmotic pumps (Alza Corp., Palo Alto, CA) were loaded with chloramphenicol in aqueous solution to deliver the compound at a rate of approximately $1000 \mathrm{mg} /$ $\mathrm{kg} / \mathrm{d}$. Thirty minutes prior to cochlca rcmoval, chicks weighing $90-110$ $\mathrm{gm}$ were deeply anesthetized and the osmotic pump placed subcutaneously. Saline filled osmotic pumps were placed subcutaneously in control animals 30 min before cochlea removal. Experimental and control animals in the $3 \mathrm{hr}$ survival group were treated with hourly intramuscular injections that administered chloramphenicol or saline at the same rate as the osmotic pumps. At 3,6 , or $12 \mathrm{hr}$ following cochlea 
removal, control and chloramphenicol-treated animals were deeply anesthetized and transcardially perfused with chick Ringer"s (154 InM $\mathrm{NaCl}, 6 \mathrm{~mm} \mathrm{KCl}, 8.4 \mathrm{~mm} \mathrm{MgCl}, 5 \mathrm{~mm}$ HEPES, $8 \mathrm{~mm}$ glucose) for $1-$ $2 \mathrm{~min}$. The brainstem was then removed and fixed by immersion in a modified Carnoy's fix ( 6 parts ethanol, 2 parts chloroform, 1 part glacial acetic acid, and 1 part $10 \times$ chick Ringer's) for $6-8$ hr at $4^{\circ} \mathrm{C}$

Amino acid incorporation. Changes in protein synthesis in NM neurons following cochlea removal were examined by studying the incorporation of tritiated amino acid ( ${ }^{3} \mathrm{H}$-leucine) according to the method described in Steward and Rubel (1985). Six hours following removal of the cochlea, $0.5 \mathrm{mCi}$ of ${ }^{3} \mathrm{H}$-leucine was administered by intracardiac injection. The animals were allowed to survive for an additional 30 min, then deeply anesthetized and transcardially perfused with $0.9 \%$ saline for 1-2 min to wash out unincorporated ' $\mathrm{H}$-leucine, followed by $4 \%$ paraformaldehyde for $10 \mathrm{~min}$.

\section{Histology}

Tissue preparation. The heads of paraformaldehyde-perfused animals were postfixed in a large volume of $4 \%$ paraformaldehyde for $12-18 \mathrm{hr}$. Fixed brainstems were dissected, blocked, thoroughly dehydrated in graded alcohols, cleared in methyl salicylate, and embedded in paraffin. Modified Carnoy's fixed brainstems were washed with threc to five changes of $70 \%$ ethanol to remove the chloroform and then dehydrated and embedded in paraffin. Brainstems were serially sectioned in the coronal plane on a rotary microtome at a thickness of $10 \mu \mathrm{m}$ for immunohistochemistry or $6 \mu \mathrm{m}$ for autoradiography. Sections were mount ed on chrome-alum-subbed glass slides and thoroughly deparaffinized prior to immunohistochemistry or autoradiography.

Autoradiography. Slides with $6 \mu$ m sections from animals labeled with ${ }^{3} \mathrm{H}$-leucine were dipped in Kodak NTB-2 emulsion diluted 1:1 in double-distilled water. After drying for at least $4 \mathrm{hr}$. emulsion-coated slides were stored in light-proot boxes at $4^{\circ} \mathrm{C}$ for $3-4$ weeks. After the appropriate exposure time, the slides were processed as previously described (Steward and Rubel, 1985). Slides that were not double labeled with Y 10B immunohistochemistry (see below) were stained with thionin after developing the emulsion and washing for $1 \mathrm{hr}$.

Immunohistochemistry. A monoclonal antibody to ribosomal RNA (rRNA) (Lerner et al., 1981 ) was obtained from Dr. Joan Steilz, Yale Univ. Initially, ascites generated by Dr. Steitz's lab was used for immunohistochemistry. In later studies, the Y10B hybridoma was obtained and a large quantity of supernatant with a high concentration of antibody was generated in cell culture facilities at the University of Washington. All solutions in the immunohistochemistry procedurc were preparcd in PBS with $1 \%$ bovine serum albumin (BSA) and $0.1 \%$ sodium azide. Deparaffinized sections were rehydrated through graded alcohols then incubated with $4 \%$ horse serum for $1 \mathrm{hr}$ and then incubated with a 1:5000 dilution of Y 10B ascites or a 1:500 dilution of supernatant from cultures of the $\mathrm{Y} 10 \mathrm{~B}$ hybridoma. Incubation with the primary antibody was carried out overnight at room temperature in a humidified chamber. After three washes (10 min) in PBS, sections were incubated with a 1:200 dilution of biotinylated horse anti-mouse secondary antibody (Vector Labs, Burlingame, CA) for 1 hr. The secondary antibody was removed with three washes $(10 \mathrm{~min})$ in PBS and the sections werc incubated with an avidin-peroxidase conjugate (Vectastain ABC Kit, Vector Labs, Burlingame, CA) in PBS without sodium azide. After washing the sections, diaminobenzidine (DAB) $(0.25 \mathrm{mg} / \mathrm{ml})$ with hydrogen peroxide $(0.1 \%$ ) in Tris buffer, $\mathrm{pH} 7.6$, was added for $10 \mathrm{~min}$ The reaction was stopped by washing the sections with PBS. Tissue labeled with ${ }^{3} \mathrm{H}$-leucine was carried through the immunohistochemical procedure detailed above. Slides were then thoroughly dehydrated with graded alcohols, dried, dipped in autoradiographic emulsion, and developed according to the procedures described above.

\section{Data analysis}

Densitometry. To quantify the difference in Y10B immunolabel present in afferent-deprived NM neurons versus intact control neurons on the other side of the same tissue section, the density of the DAB reaction product in each cell was analyzed using the BIOQUANT image analysis system (R\&M Biometrics, Nashville, TN). One section from each animal that contained 50-80 NM neurons on each side and was from the middle (30-70\% of the rostrocaudal axis) of the nucleus was selected for analysis. Every NM neuron on both the afferent-deprived and control sides of the brainstem of the selected section was visualized under a
$100 \times$ objective on a Leitz Aristoplan microscope using Nomarski optics to visualize the outline of the cytoplasmic membrane. A video camera (Dage-MTI, Michigan City, IN) transferred the image to the computer for digitizing and to a video monitor. The unstained nuclear area of each cell was outlined on the video image and the BIOQUANT program was directed to exclude the nuclear area from analysis. The cytoplasmic area was then outlined and the average optical density (OD) of immunolabel in the cytoplasm of each NM neuron was measured by the BIOQUANT program on a scale from 0 to 255 . At one seating, the experimenter measured the cytoplasmic optical density from all NM neurons on the experimental side and all neurons on the control side of the tissue section. Care was taken to make certain that the background light intensity did not change over the measurement period.

To quantify the difference in Y10B immunolabel between neurons that lose the capacity to synthesize protein and those that continued to incorporate ${ }^{3} \mathrm{H}$-leucine in the afferent-deprived $\mathrm{NM}$, lissue that had been double labeled for ${ }^{3} \mathrm{H}$-leucine incorporation and the $\mathrm{Y} 10 \mathrm{~B}$ antibody was also analyzed. Sections from double-labeled tissue were selected according to the criteria mentioned above and imaged in the same manner, but without Nomarski optics (silver grains were enhanced by Nomarski optics, which would decrease the area of immunolabel available for analysis). The BIOQUANT image analysis program was first set to a density threshold that recognized only the black area of the digitized image, which represented the silver grains. The DAB reaction product was represented in the digitized image by grays with a density below the threshold set for the silver grains. Both the nuclear area and the area of the silver grains were then subtracted from the area used to determine the optical density of the Y10B label in the cytoplasm of cach NM neuron in both sides of the section.

Statistical analysis. The quantitative and statistical analyses are similar to those described in detail in earlier publications (Born and Rubel, 1988; Hyde and Durham, 1990). Optical density (OD) scores generated by the BIOQUANT program could not be compared across animals because of interanimal differences in the density of immunohistochemical reaction product and differences in light level from section to section analyzed by our image analysis system. Therefore, for each section analyzed, all of the OD scores for each NM neuron on both sides of the section were normalized according to the following procedure. A standard score ( $z$-score) was generated for each NM neuron by normalizing all of the OD scores obtained from a given animal to the mean and standard deviation $\mathrm{OD}$ for intact, control NM neurons on the side of the section opposite the manipulation. A z-score was determined for each cell according to the formula (OD - mean of the control ODs)/ standard deviation of the control ODs. This formula provides a $z$-score that is equal to the number of standard deviations a particular OD varies from the mean OD of NM neurons from the contralateral (control) side in the same tissue section. By normalizing the $\mathrm{OD}$ of each neuron to the mean OD of control NM neurons in the same tissue section, comparisons across animals or even between tissue sections in the same animal are possible since each cell is given a score on the same scale.

To determine if there was a significant effect of afferent deprivation on Y10B immunoreactivity at various times following cochlea removal and following various treatments, the mean z-scorc for afferent-deprived neurons from each animal was treated as a single observation and combined with the mean afferent-deprived $z$-scores for all animals in that group. Significant differences between the mean afferent-deprived $\mathrm{z}$ score between each time point, and between experimental and unoperated control animals were detected by a one-way ANOVA. In order to analyze the effect of a drug treatment on the proportion of afferentdeprived neurons that displayed decreased Y $10 \mathrm{~B}$ immunoreactivity, we established a cutoff point below which a neuron was considered YlOH negative. Neurons with a $Z$-score of less than -2.0 (2 standard deviations below the mean) were designated as Y $10 \mathrm{~B}$ negative. This criterion was chosen because $\pm 2.0 \mathrm{z}$-scores approximates the $95 \%$ confidence interva for labeling of NM neurons on the control side of the brain. The mean percentages of afferent-deprived NM neurons designated as Y10B negative were averaged within each treatment group and compared using a two-way ANOVA. To assess the reliability of our analytical procedures, we made repeated measurements on several animals. Analysis of several tissue sections from a given animal demonstrated that the mean 7 -score and percentage Y $10 \mathrm{~B}$-negative cells in a single animal did not vary by more than $10 \%$ between tissue sections. Additionally, at the later survival times, when the bimodal populations have developed, the percentage of NM neurons designated as Y $10 \mathrm{~B}$ negative by $z$-score correlated well with the percentage of NM neurons that can be identified 


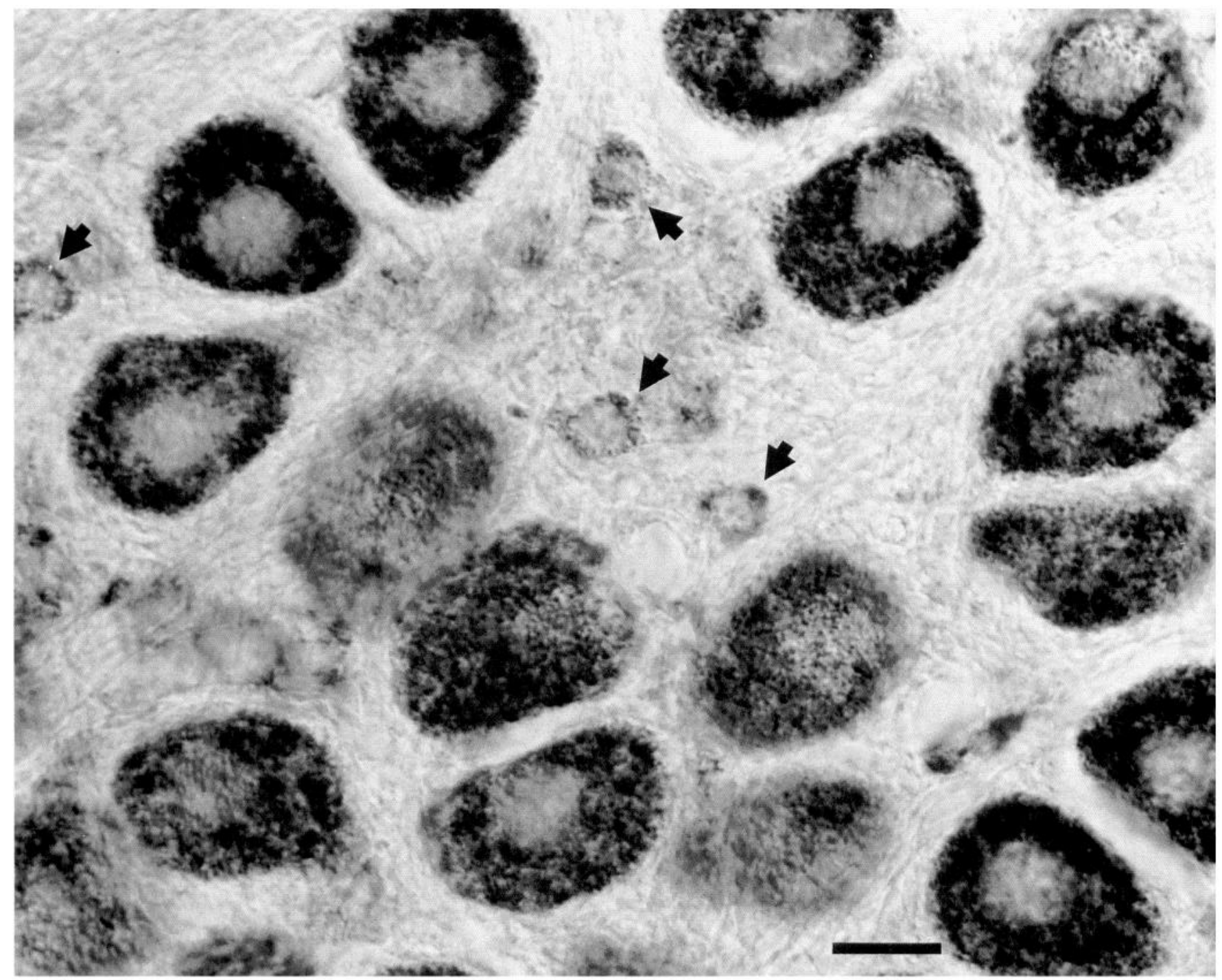

Figure 1. Y10B staining in intact NM neurons. Note the homogeneous level of staining in neuronal cytoplasm and the absence of label in the nucleus or nucleolus. Glial cells (arrows) are visible as thin rings of cytoplasmic staining surrounding an unstained nucleus. Scale bar, $10 \mu \mathrm{m}$.

visually as unstained by $\mathrm{Y} 10 \mathrm{~B}$ immunohistochemistry and the proportion of NM neurons that will eventually be lost from the nucleus.

\section{Results}

Two phases of change in Y10B immunoreactivity

To examine the ability of an antibody that recognizes rRNA to label the structural changes in ribosomes seen in NM neurons following afferent deprivation, tissue from animals killed 3, 6, 9 , or $12 \mathrm{hr}$ following cochlea removal was stained with the Y10B antibody using conventional DAB immunohistochemistry. The Y10B antibody labels the cytoplasm of every neuron in the normal brainstem with a granular pattern indicative of ribosomal staining (Fig. 1). Many glial cells, choroid cells, and meningeal cells are also labeled by this antibody. There are differences in the amount of Y10B label in different neuronal populations, but the neurons within specific nuclei are usually labeled to a similar extent. Neuronal and glial nuclei are not labeled by the Y10B antibody and one paradoxical aspect of the staining pattern is that the nucleolus, which contains a high concentration of rRNA, also does not label. Intact NM neurons demonstrate a fairly uniform amount of Y10B immunoreactivity.

Following the removal of afferent input, NM neurons undergo a biphasic change in their staining for the Y10B antibody (Fig. 2). During the first phase, $3 \mathrm{hr}$ after cochlea removal, nearly every afferent-deprived NM neuron demonstrates decreased rRNA immunoreactivity, while in the second phase, 6-12 hr following cochlea removal, two distinct populations of afferentdeprived NM neurons develop. Photomicrographs of Y10B stained NM neurons 3 and $12 \mathrm{hr}$ following cochlea removal are shown in Figure 2. The bottom photomicrograph of each pair is of NM neurons from the side of the brain ipsilateral to the cochlea removal, and pictured above are cells from the intact $\mathrm{NM}$ of the same tissue section (contralateral to the cochlea removal). At the $3 \mathrm{hr}$ time point (Fig. $2 A, B$ ), nearly all afferentdeprived NM neurons exhibit a decrease in Y 10B immunolabel. The pattern of the remaining immunoreactivity is limited to a thin rim along the cytoplasmic membrane. By $12 \mathrm{hr}$ after cochlea removal (Fig. $2 C, D$ ), there is a new pattern of $\mathrm{Y} 10 \mathrm{~B}$ staining in the deafferented NM. Two distinct populations of NM neurons 

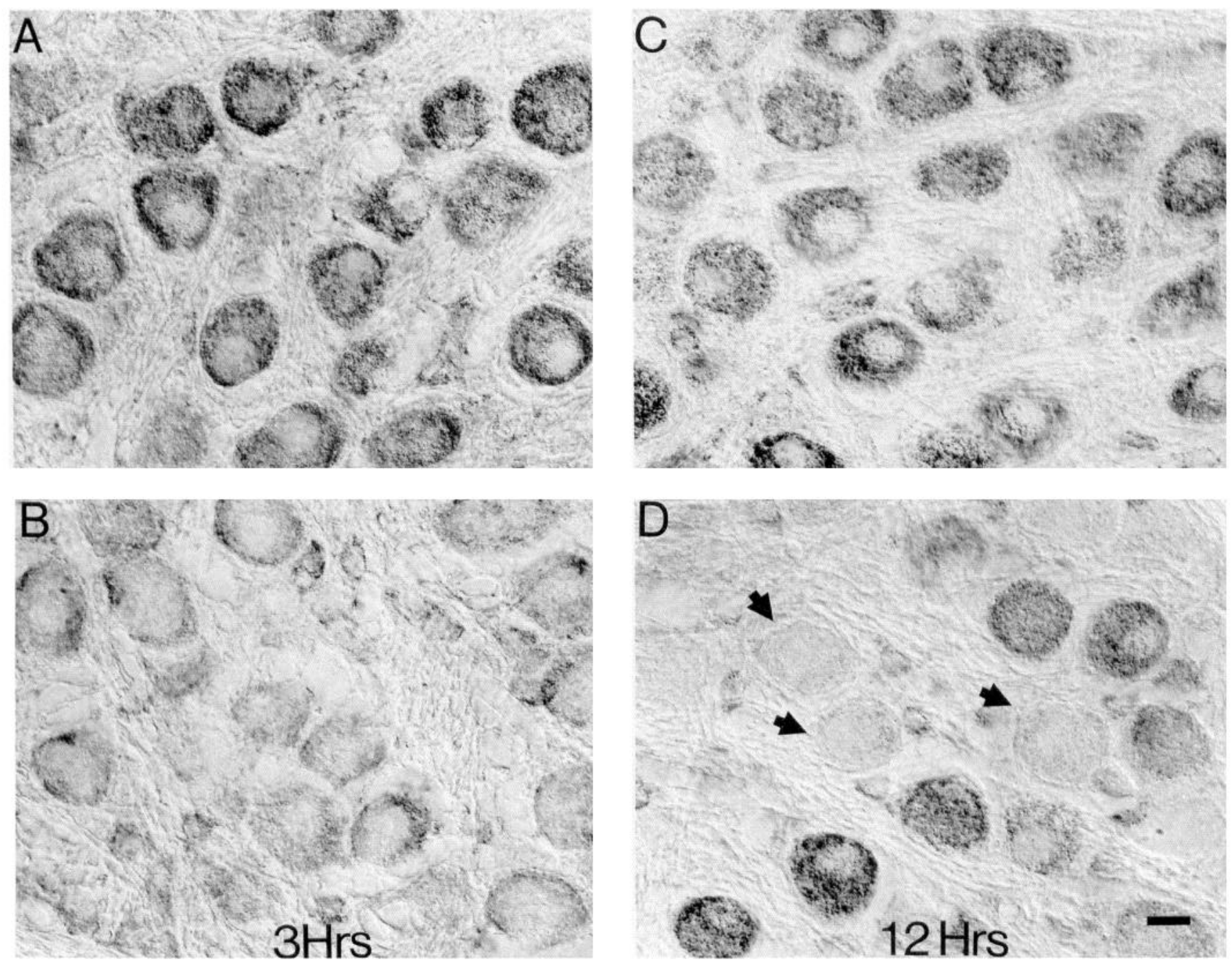

Figure 2. NM neurons immunolabeled with the Y10B monoclonal antibody to rRNA in unilaterally deafferented animals. The tissue sections are from animals killed $3 \mathrm{hr}(A, B)$ or $12 \mathrm{hr}(C, D)$ after cochlea removal. Control NM sections, contralateral to the cochlea removal $(A$, $C)$, demonstrate uniform Y10B label. A uniform decrease in Y10B label occurs $3 \mathrm{hr}$ after cochlea removal $(B)$. Twelve hours after cochlea removal $(D)$, a subset of NM neurons are Y10B negative (arrows). Scale bar, $10 \mu \mathrm{m}$.

have developed; one population appears to have regained nearly normal levels of $\mathrm{Y} 10 \mathrm{~B}$ immunoreactivity while the remaining cells are unlabeled by the $\mathrm{Y} 10 \mathrm{~B}$ antibody.

Representative distribution plots (Fig. 3) from individual animals killed 3, 6, and $12 \mathrm{hr}$ following cochlea removal illustrate how the OD of Y10B immunolabel in NM neurons changes after loss of synaptic input. These distribution plots were constructed by binning the number of NM neurons within an OD $z$-score range of 0.5 and plotting the number of neurons in each bin on the $y$-axis against the $\mathrm{z}$-score of that bin on the $\mathrm{x}$-axis. In each animal it can be seen that the contralateral NM neurons (solid bars) demonstrate a normal distribution of z-scores centered around the mean, which has a z-score of zero. The distribution of OD z-scores for deafferented NM neurons (shaded bars) is shifted to the left at $3 \mathrm{hr}$ after cochlea removal but remains normally distributed. The dramatic loss of Y10B immunoreactivity from the large majority of afferent-deprived NM neurons only $3 \mathrm{hr}$ after cochlea removal (Figs. $2 B, 3$ ) was surprising in light of only modest ultrastructural evidence of ribosome destruction at this time point (Rubel et al., 1991). Thus, loss of Y10B immunoreactivity can precede the destruction of ribosomes. During the second phase of change in ribosomal immunoreactivity, as early as 6 or $12 \mathrm{hr}$ after cochlea removal, some afferent deprived NM neurons regain Y10B immunoreactivity. By $12 \mathrm{hr}$ after cochlea removal, some NM neurons continue to shift to more negative z-scores, making the distribution appear rectangular or bimodal.

To determine if the shift in the distribution of Y10B immunoreactivity following cochlea removal occurs similarly across several animals, the OD z-scores from each animal killed 3 or $12 \mathrm{hr}$ after cochlea removal ( $n=4$ and 5 , respectively) were grouped to generate the OD distribution plots in Figure 4. Over 200 neurons are represented in the afferent deprived and contralateral sides in each plot of grouped data. The distribution plots of the grouped data demonstrate that the general pattern of change in OD of Y10B immunolabel is consistent between animals. Bimodality of the afferent-deprived distribution at 12 $\mathrm{hr}$ following cochlea removal is less evident in the grouped distribution because the nadirs seen in individual distribution plots do not occur at the same z-score. In Figure 5, the mean 

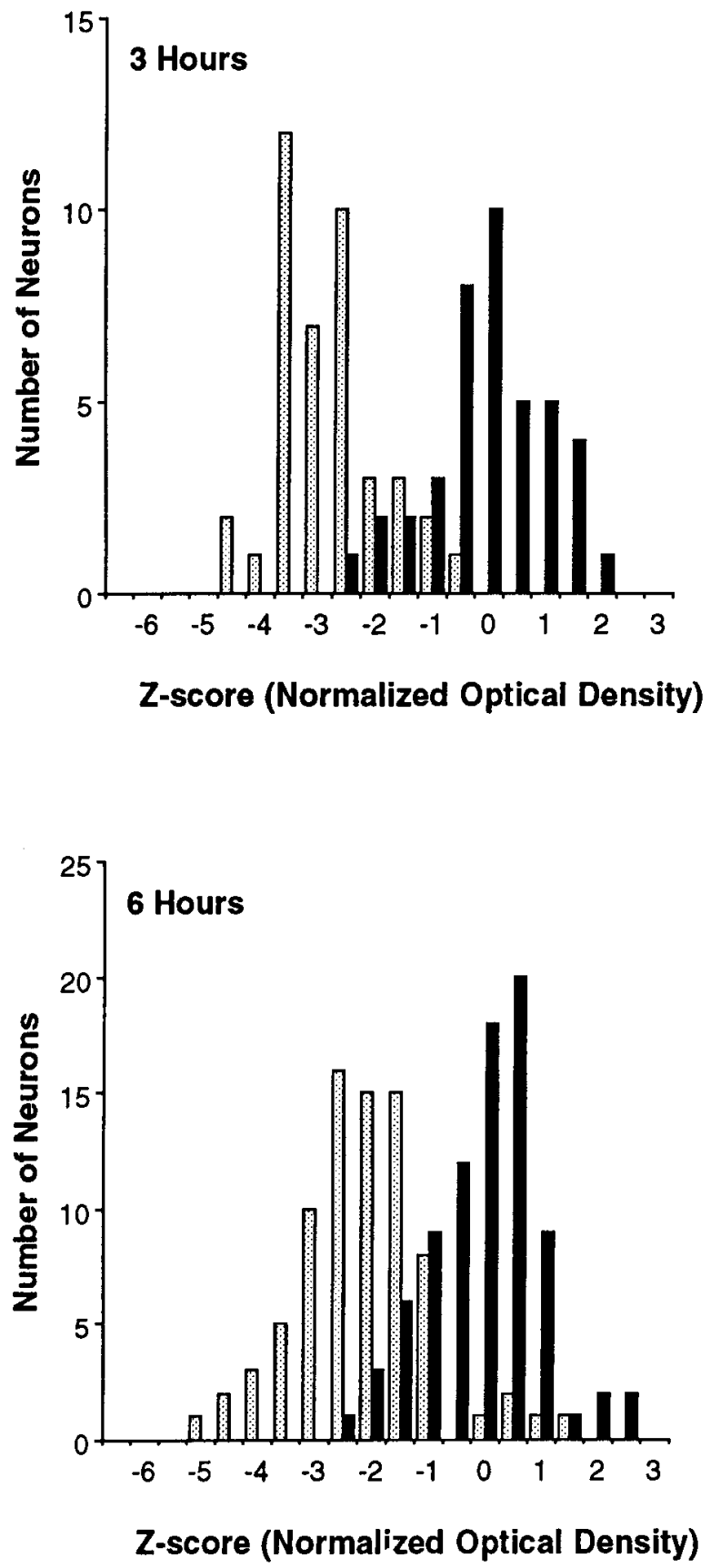
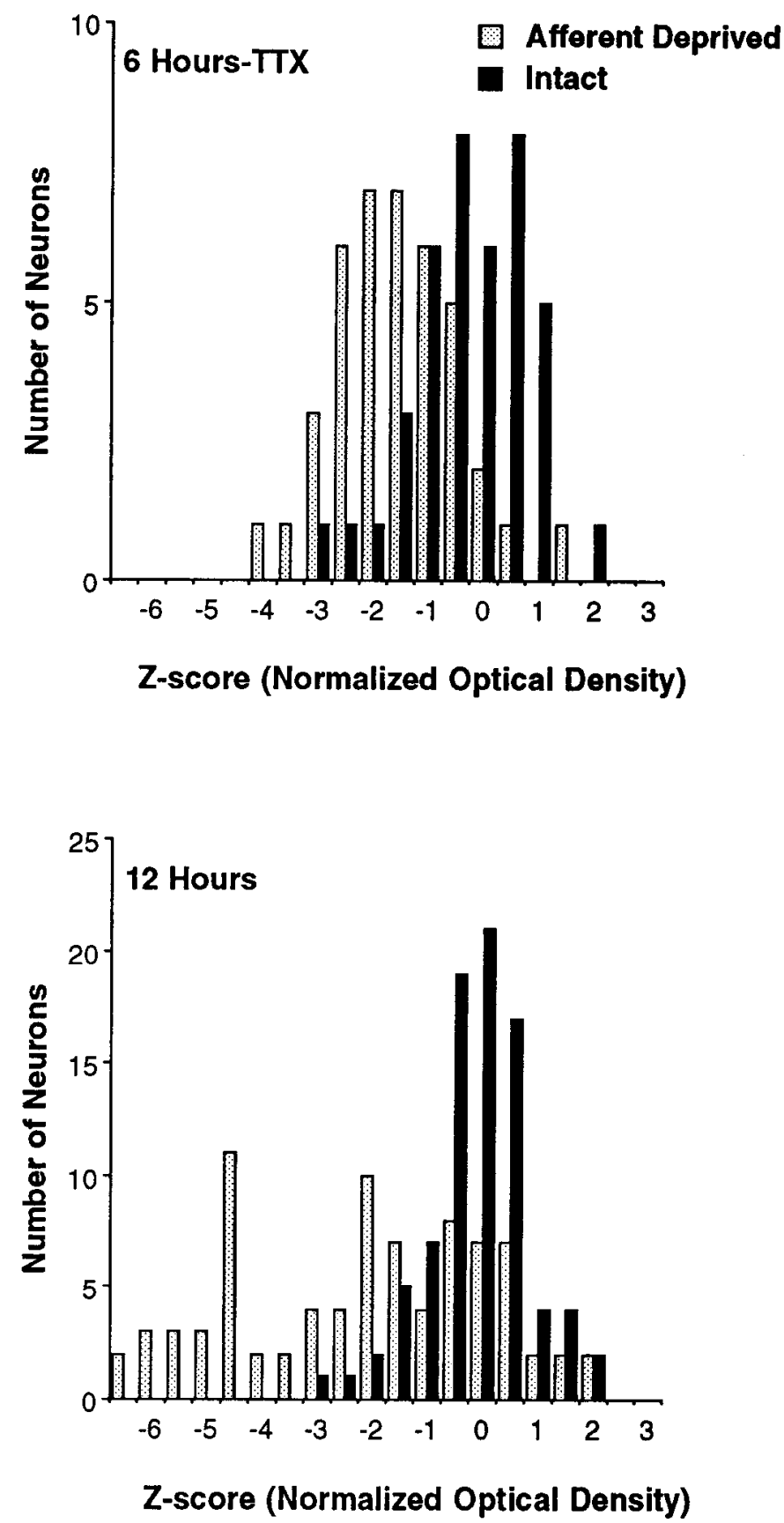

Figure 3. Distribution plots of the relative OD of Y10B immunolabel in NM neurons from individual animals killed at 3,6, or 12 hr following cochlea removal or $6 \mathrm{hr}$ of TTX blockade of eighth nerve activity. The distribution of immunolabel in control neurons from the contralateral NM is represented by the solid bars, and the distribution of the deafferented neurons is represented by the shaded bars. Each bar represents the number of neurons obtaining a z-score within $0.5 \mathrm{z}$-scores of the assigned value for the bin. Three hours after cochlea removal, most NM neurons on the affected side have lost Y10B label. Some affected neurons have recovered Y10B staining by $6 \mathrm{hr}$ after cochlea removal. By $12 \mathrm{hr}$ following cochlea removal there are two distinct populations of neurons, labeled and Y10B negative.

z-scores for Y 10B immunolabel in deafferented NM neurons 3, 6,9 , and $12 \mathrm{hr}$ following loss of synaptic activation are plotted. The peak in generalized loss of Y10B immunoreactivity occurs $3 \mathrm{hr}$ after cochlea removal, with a mean z-score of -2.38 . A one-way ANOVA demonstrated a significant decrease in mean z-score compared to unoperated controls at all four time points following deafferentation $(p<0.001)$.

\section{Synaptic activity blockade}

To determine whether the changes in Y10B immunolabel of NM neurons following cochlea removal were due to loss of electrical activity or due to some damage mechanism that is specific to cochlea removal, a slow-release compound embedded with TTX was unilaterally implanted in the inner ear of several animals. Intralabyrinthine TTX blocks electrical activity in the eighth nerve without anatomically disrupting the auditory pathway (Born and Rubel, 1988). The activity blockade was sustained for 3 or $6 \mathrm{hr}$, at which time the animals were sacrificed. The shift in distribution of Y10B label in activity-deprived NM neurons mirrored the OD distribution shift seen following unilateral cochlea removal (Fig. 3). Mean z-scores for Y10B immunolabel of NM neurons subjected to 3 or $6 \mathrm{hr}$ of eighth nerve 

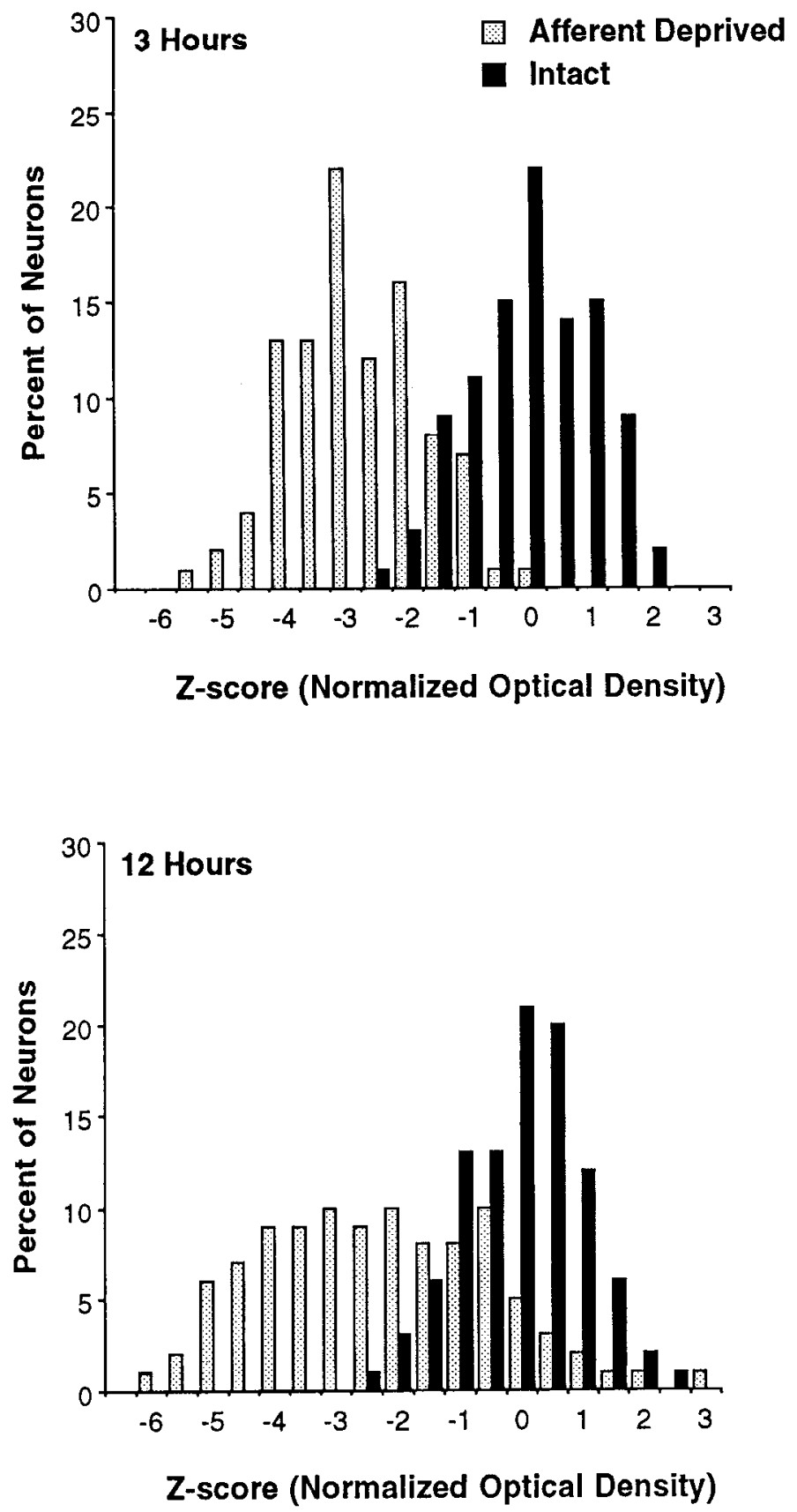

Figure 4. Grouped distribution plots of the OD of Y10B immunolabel in NM neurons from four animals killed $3 \mathrm{hr}$ following cochlea removal and from five animals killed $12 \mathrm{hr}$ following cochlea removal. The distribution of immunolabel in intact neurons from the contralateral NM is represented by the solid bars, and that of the afferent-deprived neurons is represented by the shaded bars. Each bar represents the percentage of the total number of neurons analyzed that obtained a $\mathrm{z}$-score within $0.5 \mathrm{z}$-scores of the assigned value of the bin. The development of two populations of NM neurons (labeled and Y 10B negative) by $12 \mathrm{hr}$ after cochlea removal occurs reliably in all animals as demonstrated by the grouped distribution plots.

activity blockade $(-1.25$ and -0.99 , respectively) were not significantly different from those obtained 3 or $6 \mathrm{hr}$ following cochlea removal (Student's $t$ test, $p>0.5$ ). These findings demonstrate that decreased Y10B immunoreactivity results from the loss of synaptic activation, and not from degenerative changes in the eighth nerve axons.

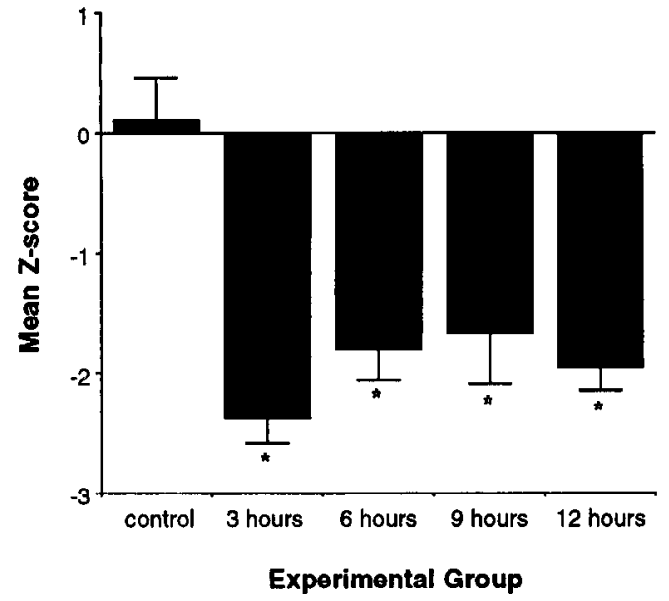

Figure 5. OD z-score means of Y10B immunolabel in NM neurons ipsilateral to cochlea removal at $3,6,9$, and $12 \mathrm{hr}$ survival. Negative $\mathrm{z}$-scores reflect the decreased Y10B immunolabel in deafferented NM neurons at all four death times. Error bars represent the SEM; asterisks indicate significant decreases as demonstrated by one-way ANOVA ( $p$ $<0.001$ ).

\section{Dying neurons are marked by ahsence of YloB label}

Previous studies have suggested that deafferented NM neurons that will degenerate over the next $2 \mathrm{~d}$ are marked by their failure to incorporate ${ }^{3} \mathrm{H}$-leucine $6-12 \mathrm{hr}$ following cochlea removal (see Discussion and Rubel et al., 1991). To determine if those neurons that are no longer synthesizing protein are the same NM neurons that have lost their rRNA immunoreactivity, immunohistochemistry with the Y10B antibody was performed on sections from animals that had been labeled for ${ }^{3} \mathrm{H}$-leucine incorporation. Following the immunolabeling procedure, the sections were coated with autoradiographic emulsion and exposed for 3-4 weeks. Figure 6 shows NM neurons deprived of afferent input for $6 \mathrm{hr}$ that have been double-labeled by ${ }^{3} \mathrm{H}$ leucine autoradiography and Y10B immunohistochemistry. NM neurons that no longer incorporate amino acid into protein are unlabeled by the Y10B antibody. This finding is consistent in every section analyzed from these animals. However, as demonstrated in Figure 6, there is also a subset of NM neurons that incorporated the ${ }^{3} \mathrm{H}$-leucine label but stained lightly for the Y10B antibody. These findings do not address whether those cells that label for ${ }^{3} \mathrm{H}$-leucine incorporation but not for $\mathrm{Y} 10 \mathrm{~B}$ will eventually regain their immunolabel or lose their ability to synthesize protein.

The mean OD z-score of the Y $10 \mathrm{~B}$ label in deafferented NM neurons that fail to incorporate ${ }^{3} \mathrm{H}$-leucine was calculated from sections of three double-labeled animals. This subset of afferentdeprived NM neurons comprised $10-15 \%$ of the neurons in the experimental nucleus. In Figure 7 , the average of the mean $\mathrm{z}$-scores for $\mathrm{NM}$ neurons not incorporating ${ }^{3} \mathrm{H}$-leucine from the three animals is compared with the average of the mean z-scores for those deafferented NM neurons from the same tissue section that continue protein synthesis. Those cells that incorporate ${ }^{3} \mathrm{H}$ leucine are modestly decreased in the level of rRNA immunoreactivity compared to neurons in the contralateral NM (averaged mean $\mathrm{z}$-score $=-0.95$ ). On the other hand, Y10B label in cells not making protein is dramatically decreased (averaged mean $\mathrm{z}$-score $=-4.76$ ) compared to contralateral neurons, and is also significantly less than the amount of immunolabel in 


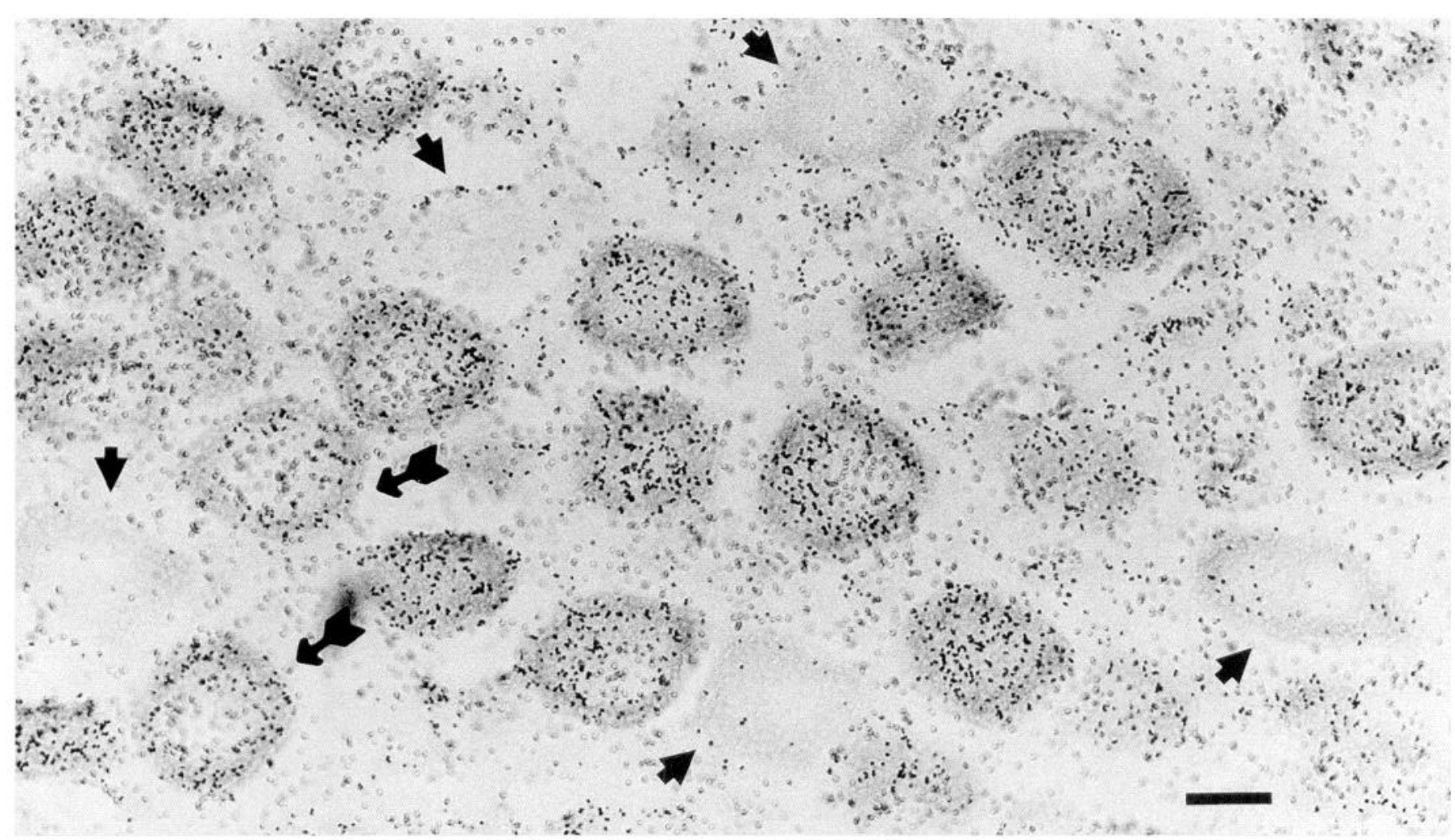

Figure 6. Neurons that have lost protein synthetic capacity are uniformly Y10B negative, while some cells with decreased Y10B immunoreactivity continue to synthesize protein. NM neurons were metabolically labeled for protein synthesis by ${ }^{3} \mathrm{H}$-leucine incorporation $6 \mathrm{hr}$ after cochlea removal and then stained with the Y10B anti-rRNA antibody. Some cells that fail to incorporate the ${ }^{3} \mathrm{H}$-leucine label (no protein synthesis) are also $\mathrm{Y} 10 \mathrm{~B}$ negative (short arrows). Neurons that have incorporated ${ }^{3} \mathrm{H}$-leucine (active protein synthesis) and are lightly labeled by the Y $10 \mathrm{~B}$ antibody are identified by the long arrows. Scale bar, $10 \mu \mathrm{m}$.

ipsilateral neurons that do incorporate the ${ }^{3} \mathrm{H}$-leucine $(p<0.02)$. These findings suggest that neurons that will eventually undergo cell death following loss of afferent input are among the pool of neurons that fail to regain rRNA immunoreactivity during the second phase of the response to afferent deprivation.

\section{The effect of cycloheximide}

To determine if the biphasic change in rRNA immunoreactivity resulted from the impact of new gene expression that might be stimulated by loss of synaptic activity, we systemically inhibited protein synthesis with the drug cycloheximide. One group of animals was treated with cycloheximide immediately prior to cochlea removal and sacrificed $3 \mathrm{hr}$ later. This experiment was designed to address whether new gene expression was necessary to bring about the initial loss of rRNA immunoreactivity. A second group of animals was treated with cycloheximide beginning $6 \mathrm{hr}$ after cochlea removal and sacrificed $3 \mathrm{hr}$ later. By preventing protein synthesis during this phase, we hoped to determine if newly synthesized proteins were required for the development of a bimodal distribution of Y10B label. Figure $8 \mathrm{~A}$ shows the results of both experiments with mean z-scores for cycloheximide-treated and untreated controls 3 or $9 \mathrm{hr}$ after cochlea removal. Student's $t$ tests show no significant difference between mean z-scores for cycloheximide-treated and untreated animals at either time point.

In order to examine the population of neurons with very low Y10B immunoreactivity, the percentage of neurons unlabeled with the Y10B antibody was determined for each animal by

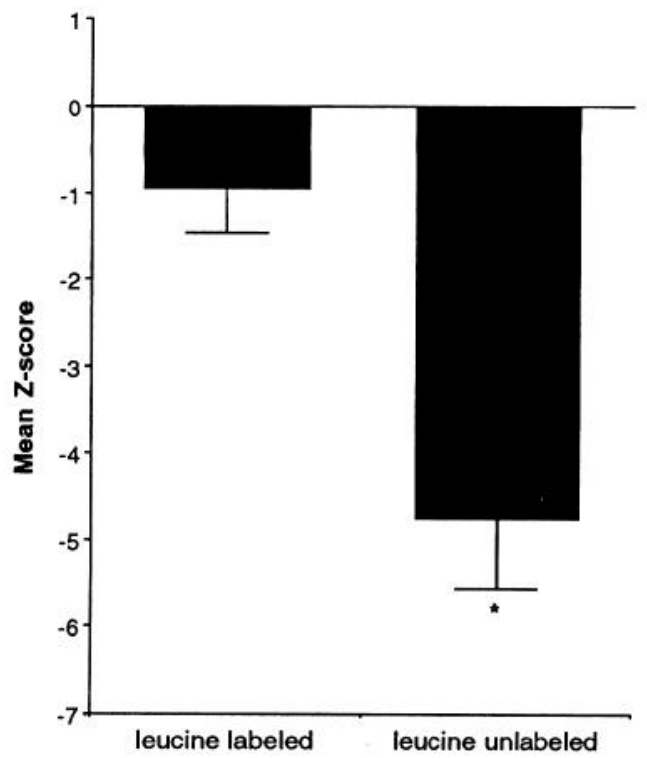

Figure 7. The mean OD z-score for Y10B immunolabel of deafferented NM neurons that fail to incorporate ${ }^{3} \mathrm{H}$-leucine $6 \mathrm{hr}$ after cochlea removal is compared to the merin OD z-score of those deafferented NM neurons that continue to synthesize protein. Error bars represent SEM. Asterisk indicates a significant decrease in mean OD z-score (Student's $t$ test, $p<0.02$ ) for NM neurons that do not incorporate ${ }^{3} \mathrm{H}$-leucine. 

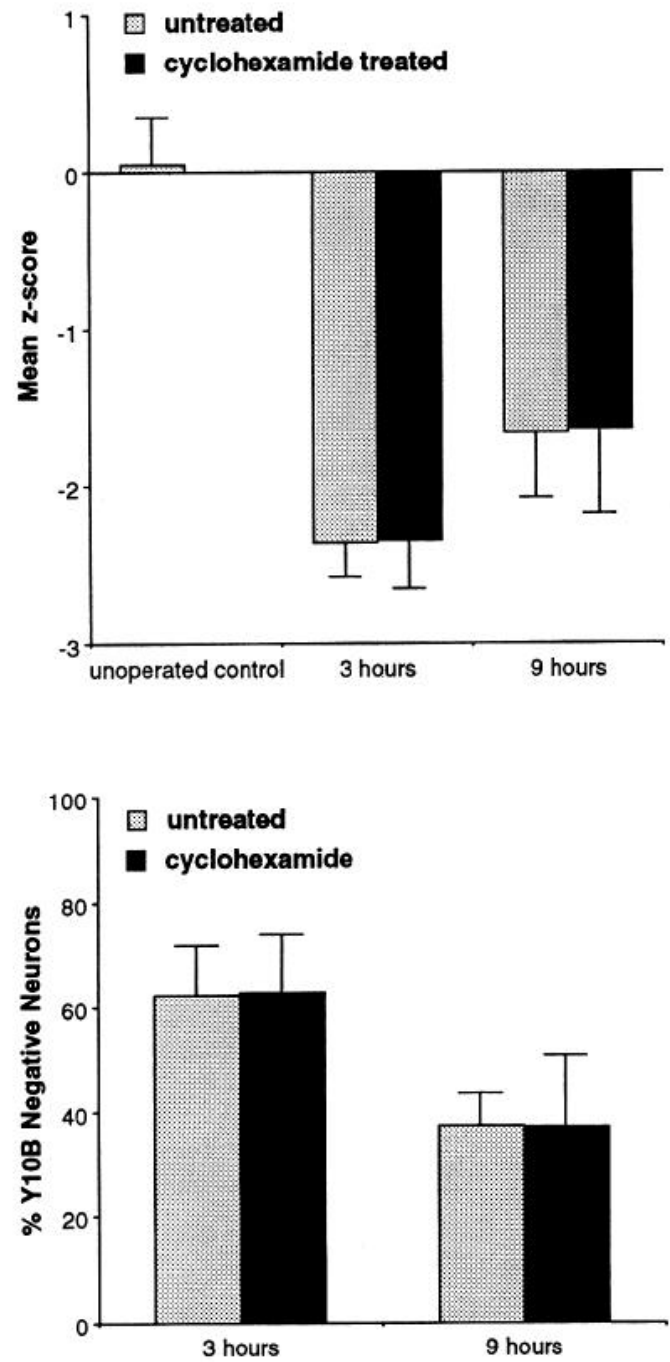

Figure 8. Cycloheximide treatment does not affect either the initial loss of Y 10B immunoreactivity in afferent-deprived neurons or the later development of Y10B-positive and Y10B-negative populations of neurons. $A, \mathrm{OD}$ z-score means of afferent deprived NM neurons from animals treated with cycloheximide for $3 \mathrm{hr}$ prior to death are compared to those from untreated animals 3 or $9 \mathrm{hr}$ after cochlea removal. $B$, The percentage of Y10B-negative NM neurons among the deafferented NM neurons does not change with cycloheximide treatment 3 or $9 \mathrm{hr}$ following cochlea removal. Error bars represent SEM.

designating any neuron with an OD outside the $95 \%$ confidence interval of the contralateral distribution (z-score $<-2.0)$ as a Y10B-negative cell. Figure $8 B$ displays the portion of Y10Bnegative neurons in NM 3 or $9 \mathrm{hr}$ after cochlea removal from cycloheximide-treated and untreated animals. There was no effect of cycloheximide treatment on the proportion of Y10Bnegative neurons at either time point. These experiments demonstrate that cycloheximide treatment had no effect on either the initial decrease in total Y10B immunolabel or the eventual distribution of that label into two populations of deafferented NM neurons. These findings indicate that the decrease in rRNA immunoreactivity following loss of synaptic input does not depend on changes in gene expression. Additionally, the ability of some NM neurons to regain rRNA immunoreactivity during the second phase of the response to afferent deprivation was not inhibited by cycloheximide treatment.
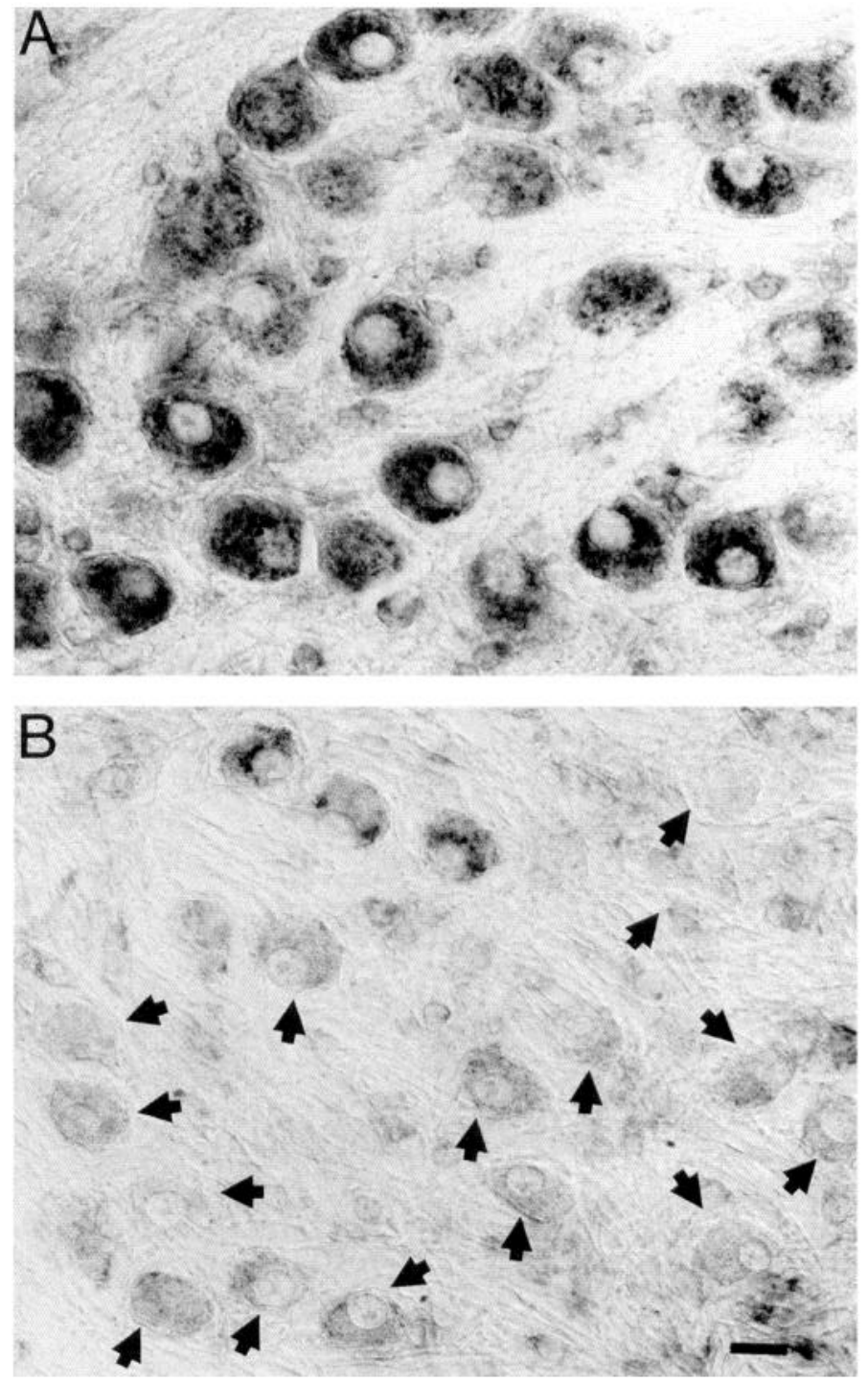

Figure 9. Chloramphenicol treatment prevents the recovery of Y10B immunoreactivity during the second phase of the response to afferent deprivation. NM neurons contralateral $(A)$ and ipsilateral $(B)$ to cochlea removal from an animal treated with chloramphenicol $(1000 \mathrm{mg} / \mathrm{kg} / \mathrm{d})$ beginning $30 \mathrm{~min}$ prior to cochlea removal and sacrificed $12.5 \mathrm{hr}$ later (modified Carnoy's fixation). The brainstem has been labeled with Y10B anti-rRNA antibody. Note the abundance of Y10B-negative neurons persisting $12 \mathrm{hr}$ after cochlea removal (arrows) as compared to Figure $2 D$. Scale bar, $10 \mu \mathrm{m}$.

\section{The effect of chloramphenicol}

To study the impact of inhibiting the upregulation of mitochondria (Rubel et al., 1990; Hyde and Durham, 1993a) on the temporal pattern of change in rRNA immunoreactivity in afferent-deprived NM neurons, chicks were treated with chloramphenicol, an inhibitor of mitochondrial protein synthesis. Chloramphenicol or vehicle was administered continuously at the rate of $1000 \mathrm{mg} / \mathrm{kg} / \mathrm{d}$ until the animals were sacrificed 3,6 , or $12 \mathrm{hr}$ after deafferentation. Figure $9, A$ and $B$, demonstrates Y10B-labeled NM neurons from the intact $(A)$ and afferentdeprived $(B)$ sides of the auditory brainstem $12 \mathrm{hr}$ following cochlea removal from an animal treated with chloramphenicol. Compared to animals receiving cochlea removal and no drug treatment (Fig. 2), there is a dramatic increase in the number 

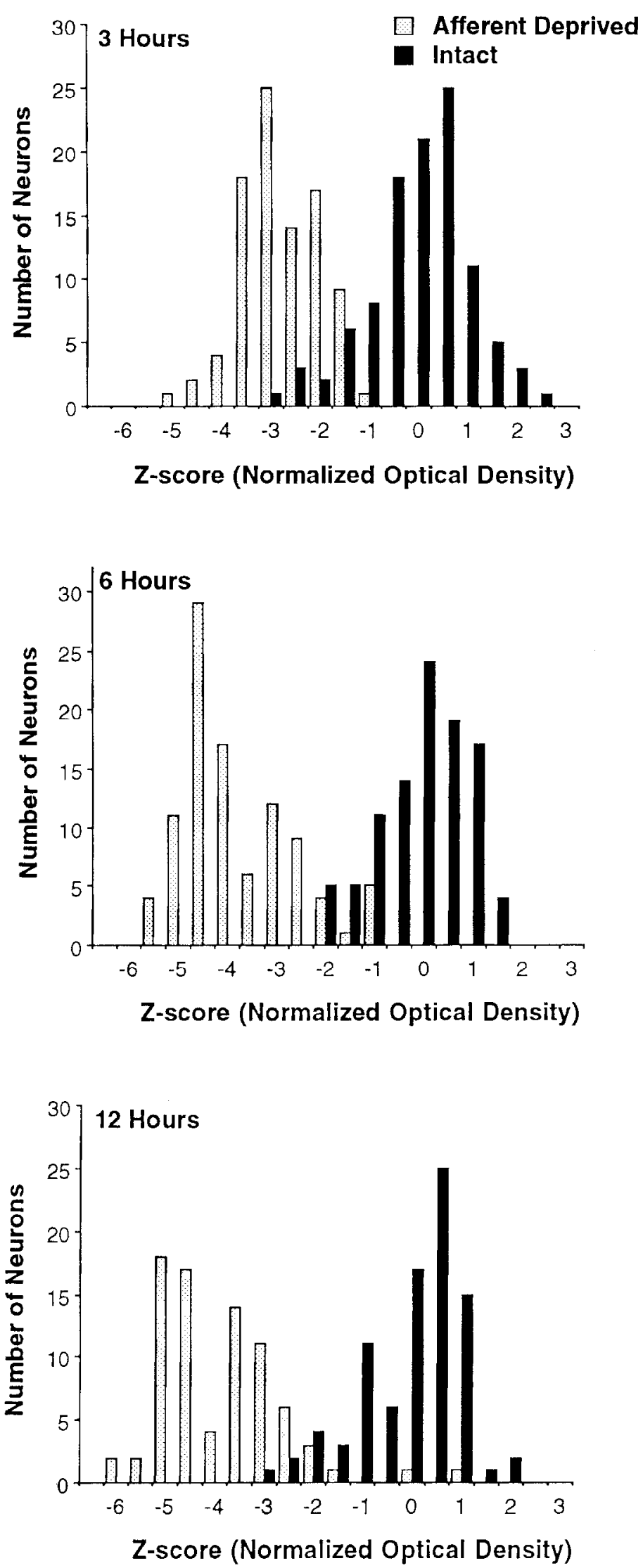

Figure 10. Chloramphenicol treatment prevents the development of a Y 10B labeled population of afferent-deprived NM neurons at 6 or 12 hr after cochlea removal. Shown here are distribution plots similar to those in Figure 3 from individual animals treated with chloramphenicol

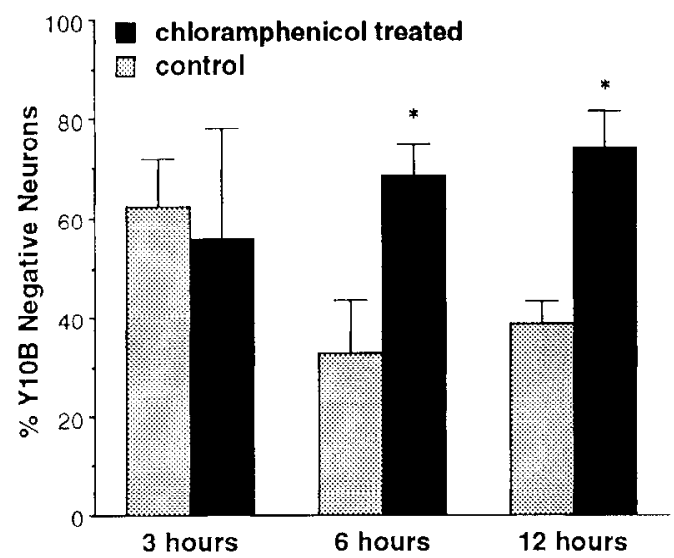

Figure 11. The percentage of deafferented NM neurons that are Y10B negative 3,6 , or $12 \mathrm{hr}$ following cochlea removal in chloramphenicoltreated animals is much greater than in untreated control animals. Error bars represent SEM; asterisks indicate that chloramphenicol-treated animals differ significantly from untreated controls $(6 \mathrm{hr}, p<0.001 ; 12$ hr, $p<0.01$ ).

of neurons that fail to regain Y YOB immunoreactivity. Chloramphenicol treatment prevents the development of a bimodal OD distribution. OD distribution plots from represcntative animals in the chloramphenicol treatment groups are displayed in Figure 10. Three hours after cochlea removal, the shift to the left in the OD distribution of afferent-deprived NM neurons is similar to the shift in untreated animals (see Fig. 3). The only change from the $3 \mathrm{hr}$ OD distributions of untreated animals is that the afferent-deprived OD distribution is further shifted to more negative z-scores. The OD distributions from chloramphenicol-treated animals 6 and $12 \mathrm{hr}$ following cochlea removal, however, are markedly different from the OD distributions of untreated animals (Fig. 3). The 6 and 12 hr OD distribution plots from chloramphenicol-treated animals demonstrate that very few cells are able to regain normal rRNA immunoreactivity.

In Figure 11 , the mean percentage of $\mathrm{Y} 10 \mathrm{~B}$-negative cells $(\mathrm{z}$ score $<-2.0$ ) from animals treated with chloramphenicol and sacrificed 3,6 , or $12 \mathrm{hr}$ following cochlea removal is compared to the mean percentage of Y $10 \mathrm{~B}$-negative neurons in vehicletreated controls. The portion of NM neurons that remain unlabeled by the Y $10 \mathrm{~B}$ antibody 6 and $12 \mathrm{hr}$ after cochlea removal is significantly elevated by the chloramphenicol treatment (twoway ANOVA showed a reliable effect of treatment; $p<0.02$ ). Post hoc comparisons using Duncan's New Multiple Range test showed a significant elevation in the number of Y10B-negative neurons at both $6 \mathrm{hr}(p<0.00 \mathrm{l})$ and $12 \mathrm{hr}(p<0.01)$ following cochlea removal. Chloramphenicol treatment produced no significant change in the percentage of Y 10B-negative neurons 3 hr after cochlea removal. These findings suggest that chloramphenicol treatment, which is known to increase the amount of deafferentation-induced neuronal death in NM neurons (Hyde and Durham, 1993a), may act by preventing NM neurons from recovering rRNA immunoreactivity and allowing a greater portion of the cells to continue along the cell death pathway.

and killed at either 3,6 , or $12 \mathrm{hr}$ following cochlea removal. Note failure of most ipsilateral neurons (solid bars) to recover enough Y $10 \mathrm{~B}$ label to obtain an $\mathrm{OD} z$-score in the normal contralateral distribution at 6 or $12 \mathrm{hr}$ following cochlea removal. 


\section{Discussion}

In this study we report a new measure of the cell death process in meurons of the afferent-deprived chick cochlear nucleus and explore how it is affected by cytoplasmic or mitochondrial protein synthesis inhibition. Our findings indicate that in response to loss of synaptic input, NM neurons demonstrate an initial decrease in immunoreactivity for the rRNA epitope recognized by the Y10B antibody. In the second phase of this response, some NM neurons are capable of regaining rRNA immunoreactivity, while others become completely $\mathrm{Y} 10 \mathrm{~B}$-negative. The correlation between the lack of Y $10 \mathrm{~B}$ label and failure to incorporate ${ }^{3} \mathrm{H}$-leucine supports the hypothesis that cells destined to die are among those that fail to regain rRNA immunoreactivity $6 \mathrm{hr}$ after cochlea removal. Preventing new gene expression through inhibition of cytoplasmic protein synthesis had no impact on the extent of initial loss or eventual recovery of rRNA immunoreactivity in afferent-deprived NM neurons. Chloramphenicol blockade of the upregulation in oxidative capacity normally observed following loss of synaptic input to NM ncurons prevents the recovery of rRNA immunoreactivity during the second phase of the response to afferent deprivation.

The remainder of this discussion will address several issues related to these data. First, the questions of what role changes in ribosome structure, as reflected by Y $10 \mathrm{~B}$ immunoreactivity, play in the cell death process and how these changes may relate to other types of neuronal death will be addressed. Second, the hypothesized cell survival process evoked in NM neurons by afferent deprivation will be discussed. Third, the intracellular signals that may be involved in initiating the changes in rRNA immunoreactivity will be considered. Finally, we will present our current working model of the intracellular responses to loss of afferent input in NM neurons.

\section{The role of ribosomes in neuronal death}

Immunolabeling afferent-deprived NM neurons with a mono. clonal antibody to rRNA, Y10B, demonstrates an intriguing temporal pattern in the immunoreactivity of ribosomes. There is an initial shift in the entire population of $\mathrm{NM}$ neurons to decreased levels of rRNA immunoreactivity $3 \mathrm{hr}$ after cochlca removal. Ultrastructural studies have shown only a modest loss of ribosomes from endoplasmic reticulum at this time point, in only a small portion of NM neurons (Rubel et al., 1991). Our findings indicate that decreased ribosomal immunoreactivity precedes ultrastructural evidence of ribosome destruction in most afferent-deprived NM neurons. This suggests that some discrete modification of rRNA that alters the Y $10 \mathrm{~B}$ epitope occurs prior to the actual destruction of the ribosome. Alternatively, decreased nuclear production of rRNA might contribute to a slow loss of rRNA immunoreactivity in the presence or normal or accelerated ribosome turnover.

In addition to marking an alteration of ribosome structure in afferent-deprived NM neurons, the loss of Y $10 \mathrm{~B}$ immunoreactivity seems to mirror the decrease in ribosome function that has been observed in previous studies. Protein synthesis initially decreases in all afferent-deprived NM neurons with an eventual segregation into two populations of cells: those that incorporate slightly less amino acid than control NM neurons, and those that cease protein synthesis entirely (Steward and Rubel, 1985; Born and Rubel, 1988; Rubel et al., 1991). The initial decrease in protein synthesis is secondary to a loss of synaptic input from the eighth nerve and cannot be reversed by antidromic depo- larization of NM neurons (Hyson and Rubel, 1989). Likewise, Y 10B immunoreactivity is specifically regulated by afferent synaptic activity, and antidromic electrical stimulation will not prevent the loss of immunoreactivity associated with afferent deprivation (Hyson and Rubel, 1992). These parallel changes in ribosome structure and function suggest that the structural alteration of the ribosome recognized by the $\mathrm{Y} 10 \mathrm{~B}$ antibody may produce the change in ribosome function measured by ${ }^{3} \mathrm{H}$ amino acid incorporation.

By 6 hr after cochlea removal, NM neurons have segregated into two populations based on rRNA immunoreactivity, ribosomal ultrastructure (Rubel et al., 1991), and the capacity to synthesize protein (Steward and Rubel, 1985; Born and Rubel, 1988). Two lines of evidence suggest that regulation of ribosomal structure and function may be an important component of the neuronal death process in NM. First, failure to incorporate ${ }^{3} \mathrm{H}$-leucine $6 \mathrm{hr}$ following cochlea removal is also strongly correlated with eventual cell loss (Steward and Rubel, 1985; Rubel et al., 1991; E. W. Rubel and O. Steward, unpublished observations), suggesting that ribosome dissociation and lack of rRNA immunoreactivity may be markers of the dying population of afferent-deprived NM neurons. Second, chloramphenicol treatment, which increases the amount of neuronal death in the afferent-deprived NM (Hyde and Durham, 1993a), also increases the portion of NM neurons that demonstrate lack of rRNA immunoreactivity and ribosome dissociation (Hartlage-Rubsamern et al., 1992).

Ribosome dissociation and destruction have been reported in several other types of neuronal death, including deafferentation-induced cell death in olfactory cortex of rats (Heimer and Kalil, 1978), developmental neuronal death in chick motor neurons (Chu-Wang and Oppenheim, 1978), chick ciliary ganglion neurons (Pilar and Landmesser, 1976), and rat retina (Cunningham, 1982) and the ventral ganglia of the moth Manduca sexta during adult metamorphosis (Stocker et al., 1978). There are also reports of ribosome dissociation in neurons undergoing delayed neuronal death following ischemia (Petito and Pulsineli, 1984; Yamamoto et al., 1990) or exposure to toxic levels of glutamate in the absence of serum growth factors in vitro (Dux ct al., 1992). None of these reports has directly linked early changes in the ultrastructure of neuronal ribosomes to eventual cell death by what has been labeled an apoptotic mechanism, which includes chromatin condensation and DNA cleavage (Wyllie et al., 1984; Clarke, 1990). However, ribosome dissociation has been reported as an early step in the cell death process of a preglial cell line, serum-free mouse embryo cells, which eventually die by a process that closely resembles the nuclear changes seen in apoptosis (Rawson et al., 1991). Additionally, chromatin condensation produces pyknotic nuclei, which are commonly observed in developing chick ventral spinal cord during developmental motor neuron death when some of these neurons also exhibit a loss of ribosomes (Chu-Wang and Oppenheim, 1978; Oppenheim et al., 1990).

Our approach has been to study the earliest events following the loss of synaptic activation in order to establish whether a neuron's initial response may be to turn on a cell death program. Causal links between early changes in dying neurons like ribosome degradation and the later development of an apoptotic morphology or the eventual death of the neurons may be even more elusive to identify. Application of the Y10B antibody to additional neuronal populations and during other types of ne.1ronal death, such as occurs during normal development, after 
growth factor deprivation and following ischemic or excitotoxic injury, may help to answer many questions about the role of ribosomes in neuronal death.

\section{Cell survival mechanisms}

A second phase in the response of NM neurons to afferent deprivation involves recovery of rRNA immunoreactivity in a subpopulation of neurons. Recovery of rRN $\Lambda$ immunoreactivity appears to mark NM neurons that will survive deafferentation. This is suggested by the ability of all Y10B-positive cells to incorporate ${ }^{3} \mathrm{H}$-leucine $6 \mathrm{hr}$ after cochlea removal. In addition, the size of the Y10B-negative population after $12 \mathrm{hr}$ of afferent deprivation approximates the size of the population that will eventually die.

We find that the recovery of rRNA immunoreactivity can be prevented by using chloramphenicol to block the ability of a deafferented neuron to increase oxidative metabolism and mitochondrial density. Previous studies from our laboratory have demonstrated that chloramphenicol treatment for the first 12 hr of afferent deprivation will produce a large increase in the number of $\mathrm{NM}$ neurons that have degenerated by $5 \mathrm{~d}$ after cochlca removal (Hyde and Durham, 1993a). Ultrastructural studies of afferent-deprived NM neurons from chloramphenicol-treated animals have also demonstrated that there is a significant increase in the number of cells that demonstrate complete ribosomal degradation at 6 or $12 \mathrm{hr}$ following cochlea removal (Hartlage-Rubsamen et al., 1992).

There are two implications of the finding that chloramphenicol treatment produces an increase in the proportion of NM neurons that display the same early changes as those seen in neurons subjected to afferent deprivation alone. First, the lack of a pathologic process separate from the one seen with afferent deprivation alone suggests that the increased cell death induced by chloramphenicol results from the mechanisms associated with afferent deprivation, and not through a separate toxic interaction between chloramphenicol and loss of synaptic input. Second, these findings suggest that the cell death process involving ribosome destruction and the cell survival process involving mitochondrial upregulation are two distinct and opposing responses to deafferentation. This hypothesis is supported by the finding that the cell survival process can be attenuated by inhibition of mitochondrial upregulation while the cell death process continues.

Two issues are raised by a putative cell survival program involving the upregulation of mitochondrial function. The finding that mitochondrial function is an important component of the cell survival process is intriguing in light of reports that the proto-oncogene $b c /-2$, which prevents programmed cell death, is localized to mitochondria (Hockenbery et al., 1990; Monaghan et al., 1992). The normal cellular function of bcl-2 is unknown. However, overexpression of $b c l-2$ can prevent apoptotic cell death even in the absence of mitochondria (Jacobson et al., 1993). Several authors have demonstrated that $b c l 2$ is also associated with nuclear membrane and endoplasmic reticulum (Chen-Levy et al., 1989; Alnemri et al., 1992; Jacobson et al., 1993). It is possible that the two organelle systems most prominent in NM neuronal death may be linked by the function of $b c t-2$. Efforts to determine if $b c l-2$ expression is altered by deafferentation are ongoing in our laboratory.

The second issue suggested by the presence of a cell survival program concerns the function that this program plays during the critical period of development when neurons are susceptible to loss of afferent input. It has been recognized for many years that neurons in young animals appear to be more susceptible to afferent deprivation, target cell removal, axotomy, or other insults (Cowan, 1970; Globus, 1975; Kalil, 1980; Hashisaki and Rubel, 1989; Snider et al., 1992). Future studies should address the question of whether an increase in the relative influence of the cell survival program with maturity may account for the differential effects of afferent deprivation or other insults in young versus aduli animals.

\section{Intracellular effectors of a neuronal death signal}

Several investigators of neuronal death during development or following trophic factor deprivation in vitro have found that inhibition of transcription or translation may prevent cell death (Martin et al., 1988; Oppenheim et al., 1990; Scott and Davies, 1990; Edwards et al., 1991). These studies suggest that the cell death signal is transduced at the level of the nucleus through alterations in gene expression. However, there are several recent examples of other cell types in which physiologic cell death and survival are regulated independent of macromolecular synthesis (Rukenstein et al., 1991; Owens and Cohen, 1992). In this study, we demonstrate that new protein synthesis is not necessary to induce the initial changes in ribosome immunoreactivity or for the eventual recovery of rRNA immunoreactivity. Thus, the dramatic changes in ribosomal structure and function during the first $3-9$ hrafter afferent deprivation are initiated by enzymes constitutively expressed in NM neurons of young animals. These findings, in conjunction with other examples of physiologic cell death that are not dependent on protein synthesis, suggests that transduction of a cell death signal may take place outside of the nucleus in some cell types.

Several signal transduction mechanisms that do not directly involve alteration of gene expression have been implicated in the physiologic death of neuronal cells. CAMP and CAMP analogs can promote neuronal survival of NGF-deprived PC12 cells (Rukenstein et al., 1991), cultured retinal ganglion cells subjected to a blockade of afferent synaptic activity with TTX (Kaiser and Lipton, 1990) and NGF-deprived, cultured sympathetic neurons (Edwards et al., 1991: Martin et al., 1992). Another second messenger involved in preventing neuronal death is cytosolic free $\mathrm{Ca}^{2}$ (Franklin and Johnson, 1992). $\mathrm{Ca}^{2+}$ influx through voltage-dependent $\mathrm{Ca}^{2+}$ channels or $\mathrm{Ca}^{2+}$ release from intracellular stores can prevent the death of NGF-deprived sympathetic neurons in culture (Kioke et al., 1989). The ras protooncogene also promotes neuronal survival, even in the absence of neurotrophic factors, when an oncogenically activated form is introduced into cultured neurons (Borasio et al., 1989). These three intracellular effectors, $\mathrm{CAMP}, \mathrm{Ca}^{2-}$ and ras, can influence the activity of intracellular protein kinases. It is possible that removal of afferent activity from NM neurons produces a change in the activation of protein kinases, and that the subsequent alteration of protein phosphorylation induces the early changes observed in ribosomes during the cell death process.

\section{A model of an NM neuron's response to afferent deprivation}

The findings presented here, in conjunction with previous studies of afferent-deprived NM neurons, support a general model of the carly response in NM neurons to the loss of afferent innervation. Figure 12 is a schematic summarizing intracellular changes found in young NM neurons following afferent deprivation. The initial changes, schematized in the second cell of Figure 12, are observed in nearly all afferent-deprived NM neu- 


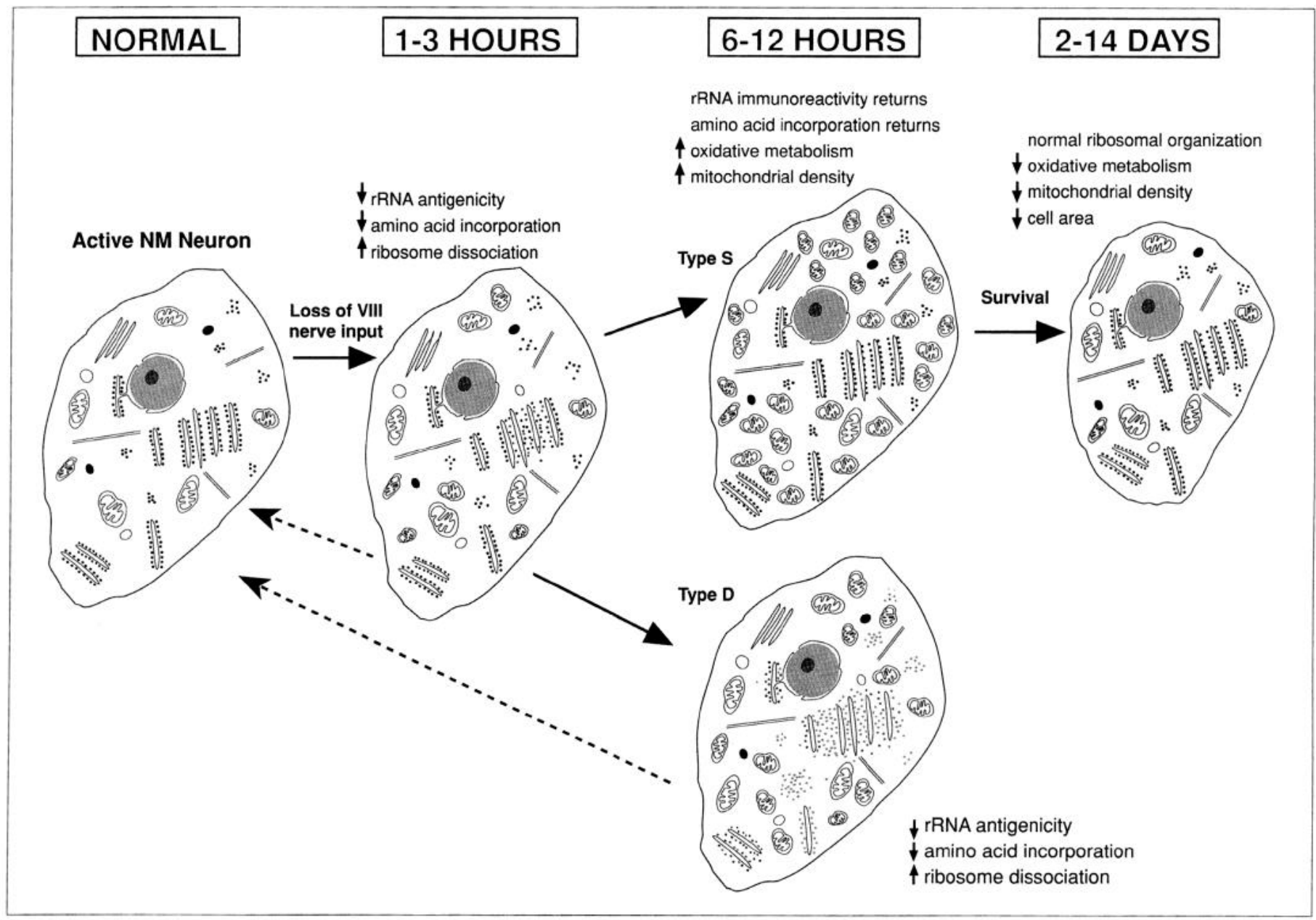

Figure 12. Model of neuronal responses to afferent deprivation in the chick cochlear nucleus (see Discussion).

rons. Changes associated with the initial response to afferent deprivation include decreased incorporation of amino acids into protein (Steward and Rubel, 1985; Born and Rubel, 1988; Hyson and Rubel, 1989), modest structural change in the organization of ribosomes on rough endoplasmic reticulum (Rubel et al., 1991), and the decreased immunoreactivity for rRNA reported in this study. During the second phase of the response to afferent deprivation, NM neurons tend to segregate into two populations. We have designated the two populations of neurons as exhibiting type $\mathrm{S}$ (survival) or type $\mathrm{D}$ (degeneration) responses, shown schematically in the 6-12 $\mathrm{hr}$ column of the diagram.

A type $S$ response involves the return of immunoreactivity for rRNA, attenuation of the loss of protein synthetic capacity, increased activity of oxidative enzymes and increased mitochondrial density. A cell's ability to mount a type $S$ response is altered by the action of chloramphenicol. Chloramphenicol treatment prevents two components of the type $\mathrm{S}$ response: mitochondrial upregulation and return of rRNA immunoreactivity, and increases the portion of afferent-deprived NM neurons that eventually die. These findings suggest that the type $\mathrm{S}$ response represents the path toward survival of an afferentdeprived NM neuron.

The type $\mathrm{D}$ response includes cessation of protein synthesis, continued loss of rRNA immunoreactivity, and complete ri- bosomal degradation. It should be noted that up to $12 \mathrm{hr}$ after afferent deprivation is initiated, the return of synaptic input (broken arrows in Fig. 12) can "save" cells that have already mounted a type D response (Born and Rubel, 1988). If the functional deafferentation is extended beyond approximately 12 $\mathrm{hr}$, we hypothesize that neurons that demonstrate a type D response will eventually die and be removed from the nucleus, presumably by phagocytic action of surrounding non-neuronal cells. Currently, there is little knowledge of what occurs between $12 \mathrm{hr}$ after cochlea removal and $48-72 \mathrm{hr}$ when the dying neurons disappear from the nucleus.

If an NM neuron survives deafferentation, rRNA immunoreactivity returns to normal levels (G. A. Garden and E. W Rubel, unpublished observations) whereas oxidative enzyme activity is permanently decreased (Durham and Rubel, 1985; Hyde and Durham, 1990; Durham et al., 1993). Mitochondrial density in deafferented NM neurons decreases to a level below control NM neurons by 2 weeks following cochlea removal (Hyde and Durham, 1993b). These changes in oxidative metabolism and mitochondria probably reflect the decreased metabolic activity required for electrically silent and atrophied neurons. Another lasting change in NM neurons that survive the loss of synaptic activity is a reduction in perikaryal volume by approximately $30-40 \%$ (Born and Rubel, 1985).

Loss of synaptic input to NM neurons causes all of the cellular 
events outlined above. The extent to which the mechanism for any of the changes demonstrated in afferent-deprived NM neurons is recapitulated in other neuronal death paradigms is not known. However, it is unlikely that this question can be adequately addressed until more specific knowledge is generated on the molecular events involved in producing the changes in oxidative metabolism or ribosome structure and function. With markers of these changes that have been developed recently or are currently being developed, the avian brainstem auditory system appears well suited for investigating the interaction between cellular events leading to neuronal death and neuronal survival following afferent deprivation.

\section{References}

Al Goul W, Miller M (1989) Transient expression of Alz-50 immunoreactivity in developing rat neocortex: a marker for naturally occurring neuronal death? Brain Res 481:361-367.

Alnemri ES, Robertson NM, Fernandes TF, Croce CM, Litwack G (1992) Overexpressed full-length human BCL2 extends the survival of baculovirus-infected Sf9 insect cells. Proc Natl Acad Sci USA 89: 7295-7299.

Borasio GD, John J, Wittinghofer A, Barde Y-A, Sendtner M, Heumann $\mathrm{R}$ (1989) ras $\mathrm{p} 21$ protein promotes survival and fiber outgrowth of cultured embryonic neurons. Neuron 2;1087-1096.

Born DE, Rubel EW (1985) Afferent influences on brain stem auditory nuclei of the chicken: neuron number and size following cochlea removal. J Comp Neurol 231:435-445.

Born DE, Rubel EW (1988) Afferent influences on brain-stem auditory nuclei of the chicken: presynaptic action potentials regulate protein synthesis in nucleus magnocellularis neurons. J Neurosci 8:901-919.

Canady KS, Rubel EW (1992) Rapid and reversible astrocytic reaction to afferent activity blockade in chick cochlear nucleus. J Neurosci 12: 1001-1009.

Chen-Levy S, Nourse J, Clcary ML (1989) The bcl-2 candidate protooncogene product is a 24 -kilodalton integral-membrane protein highly expressed in lymphoid cell lines and lymphomas carrying the $t(14$ : 18) translocation. Mol Cell Biol 9:701-710.

Chu-Wang JW, Oppenheim RW (1978) Cell death of motoneurons in the chick embryo spinal cord. I. A light and electron microscopic study of naturally occurring and induced cell loss during development. J Comp Neurol 177:33-58.

Cidlowski JA (1982) Glucocorticoids stimulate ribonucleic acid degradation in isolated rat thymocytes in vitro. Endocrinology 111:184190.

Clarke PGH (1990) Developmental cell death: morphological diversity and multiple mechanisms. Anat Embryol (Berl) 181:195-213.

Cowan WM (1970) Anterograde and retrograde transneuronal degencration in the central and peripheral nervous system. In: Contemporary research methods in neuroanatomy (Nauta WJH, Ebbesson SOE, eds), pp 217-251. New York: Springer.

Cunningham TJ (1982) Naturally occurring neuron death and its regulation by developing neural pathways. Int Rev Cytol 74:163-186.

Durham D, Rubel EW (1985) Afferent influences on brain stem auditory nuclei of the chicken: changes in succinate dehydrogenase activity following cochlea removal. J Comp Neurol 231:446-456.

Durham D, Matschinsky FM, Rubel EW (1994) Altered malate dehydrogenase activity in $\mathrm{n}$. magnocellularis of the chicken following cochlea removal. Hearing Res 70:151-159.

Dux F, Oschlies IJ, Wiessner C, Hossmann KA (1992) Glutamateinduced ribosomal disaggregation and ultrastructural changes in rat cortical neuronal culture: protective effect of horse serum. Neurosci Lett 141:173-176.

Edwards SN, Buckmaster AE, Tolkovsky AM (1991) The death program in cultured sympathetic neurones can be suppressed at the posttranslational level by nerve growth factor, cyclic AMP and depolarization. J Neurochem 57:2140-2143.

Ellis RE, Yuan J, Horvitz HR (1991) Mechanisms and functions of cell death. Annu Rev Cell Biol 7:663-698.

Franklin JL, Johnson EM (1992) Suppression of programmed neuronal death by sustained elevation of cytoplasmic calcium. Trends Neurosci 15:501-508.
Garcia I, Martinou I, Tsujimoto Y, Martinou J-C (1992) Prevention of programmed cell death of sympathetic neurons by the $b c l-2$ protooncogene. Science 258:302-304.

Globus A (1975) Brain morphology as a function of presynaptic morphology and activity. In: The developmental neuropsychology of sensory deprivation (Riesen AH, ed), pp 9-91. New York: Academic.

Hartlage-Rubsamen M, Cunningham DE, Rubel EW (1992) Chloramphenicol enhances ribosomal dissociation in deafferented neurons of the chick brainstem. Soc Neurosci Abstr 18:54.

Hashisaki GT, Rubel EW (1989) Age-related effects of unilateral cochlea removal on anteroventral cochlear nucleus in developing gerbils. J Comp Neurol 283:465-473.

I Ieimer L, Kalil R (1978) Rapid transneuronal degeneration and death of cortical neurons following removal of the olfactory bulb in adult rats. J Comp Neurol 178:559-610.

Hockenbery D, Nunez G, Milliman C, Schreiber RD, Korsmeyer SJ (1990) $B c l-2$ is an inner mitochondrial membrane protein that blocks programmed cell death. Nature 348:334-336.

Hyde GE, Durham D (1990) Cytochrome oxidase response to cochlea removal in chicken auditory brainstem neurons. J Comp Neurol 297: 329-339.

Hyde GE, Durham D (1994a) Increased deafferentation-induced cell death in chick brainstem auditory neurons following blockade of mitochondrial protein synthesis with chloramphenicol. J Neurosci 14: 291-300.

Hyde GE, Durham D (1994b) Rapid increase in mitochondrial volume in nuclcus magnoccllularis neurons following cochlea removal. J Comp Neurol 339:27-48.

Hyson RL, Rubel EW (1989) Transneuronal regulation of protein synthesis in the brain-stem auditory system of the chick requires synaptic activation. J Neurosci 9:2835-2845.

Hyson RL, Rubel EW (1992) Activity-dependent regulation of ribosomes in the chick cochlear nucleus. Assoc Res Otolaryngol 15:56.

Jacobson MD, Burne JF, King MP, Miyashita I, Reed JC, Raff MC (1993) Bcl-2 blocks apoptosis in cells lacking mitochondrial DNA. Nature 361:365-368.

Kaiser PK, Lipton SA (1990) VIP-mediated increase in cAMP prevents tetrodotoxin-induced retinal ganglion cell death in vitro. Neuron $5: 373-381$.

Kalil R (1980) A quantitative study of the effects of monocular enucleation and deprivation on cell growth in the dorsal lateral geniculate nucleus of the cat. J Comp Neurol 189:483-524.

Kioke T, Martin DP, Johnson EM (1989) Role of $\mathrm{Ca}^{2+}$ channels in the ability of membrane depolarization to prevent neuronal death induce by trophic-factor deprivation: evidence that levels of internal $\mathrm{Ca}^{2+}$ determine nerve growth factor dependence of sympathetic ganglion cells. Proc Natl Acad Sci USA 86:6421-6425.

Lerner EA, Lerner MR, Janeway CA, Steitz JA (1981) Monoclonal antibodies to nucleic acid-containing cellular constituents: probes for molecular biology and autoimmune disease. Proc Natl Acad Sci USA 78:2737-2741.

MacDonald RG, Cidlowski JA (1982) Glucocorticoids inhibit precursor incorporation into protein in splenic lymphocytes by stimulating protein degradation and expanding intracellular amino acid pool. Biochim Biophys Acta 717:236-240.

Martin DP, Schmidt RE, DiStefano PS, Lowry OH, Carter JG, Johnson EM (1988) Inhibitors of protein synthesis and RNA synthesis prevent neuronal death caused by NGF deprivation. J Cell Biol 106: 829-844.

Martin DP, Ito A, Horigome K, Lampe PA, Johnson EM (1992) Biochemical characterization of programmed cell death in NGF-deprived sympathetic neurons. J Neurobiol 23:1205-1220.

Monaghan P, Robertson D, Amos AS, Dyer MJS, Mason DY, Greaves MF (1992) Ultrastructural localization of Bcl-2 protein. J Histochem Cytochem 40:1819-1825.

Oppenheim RW, Prevette D, Tytel M, Homma S (1990) Naturally occurring and induced neuronal death in the chick embryo in vivo requires protein and RNA synthesis: evidence for the role of cell death genes. Dev Biol 138:104-113.

Owens GP, Cohen JJ (1992) Identification of genes involved in programmed cell death. Cancer Metast Rev 11:149-156.

Petito CK, Pulsineli WA (1984) Delayed neuronal recovery and neuronal death in rat hippocampus following sever cerebral ischemia: possible relationship to abnormalities in neuronal processes. J Cereb Blood Flow Metab 4:194-205. 
Pilar G, Landmesser L (1976) Ultrastructural differences during embryonic cell death in normal and peripherally deprived ciliary ganglia. J Cell Biol 68:339-356.

Rawson CL, Loo DT, Duimstra JR, Hedstrom OR, Schmidt EE, Barns DW (1991) Death of seruml-free mouse embryo cells caused by epidermal growth factor deprivation. J Cell Biol 113:6471-6480.

Rubel EW, Hyson RL, Durham D (1990) Afferent regulation of neurons in the brain stem auditory system. J Neurobiol 21:169-196.

Rubel EW, Falk PM, Canady KS, Steward O (1991) A cellular mechanism underlying the activity-dependent transneuronal degeneration: rapid but reversible destruction of the neuronal ribosomes. Brain Dysfunct 4:55-74.

Rukenstein A, Rydel RE, Green LA (1991) Multiple agents rescue PC. 2 cells from serum-free cell death by translation- and transcription-independent mechanisms. J Neurosci 11:2552-2563.

Scott SA, Davies AM (1990) Inhibition of protein synthesis prevents cell death in sensory and parasympathetic neurons deprived of neurotrophic factor in vitro. J Neurobiol 21:630-638.

Snider WD, Elliot JL, Yan Q (1992) Axotomy-induced neuronal death during development. J Neurobiol 23:1231-1246.
Steward O, Rubel EW (1985) Afferent influences on brain stem auditory nuclei of the chicken: cessation of amino acid incorporation as an antecedent to age-dependent transneuronal degeneration. J Comp Neurol 231:385-395.

Stocker RF, Edwards JS, Truman JW (1978) Fine structure of degenerating moth abdominal motor neurons after eclosion. Cell Tissue Res 191:317-331.

Vaux DL, Weissman IL, Kim SK (1992) Prevention of programmed cell death in Caenorhabditis elegans by human bcl-2. Science 258 1955-1957.

Wyllie AH, Morris RG, Smith AL, Dunlop D (1984) Chromatin cleavage in apoptosis association with condensed chromatin morphology and dependence on macromolecular synthesis. J Pathol 142:67-77.

Yamamoto K, Hayakawa T, Mogami H, Akai F, Yanagihara T (1990) Ultrastructural investigation of the CAl region of the hippocampus after transient cerebral ischemia in gerbils. Acta Neuropathol (Bcrl) $80: 487-492$. 